\title{
MUERTE Y RESURRECCIÓN. LA PASIÓN DE CRISTO VISTA POR EL SÉPTIMO ARTE
}

\author{
Clementina Calero Ruiz \\ Universidad de La Laguna
}

\section{RESUMEN}

En este artículo pretendemos hacer un recorrido por algunas películas que tienen a Jesús como protagonista, especialmente en aquellos acontecimientos relacionados con su Pasión, Muerte y Resurrección. Analizando iconográficamente cómo han cambiado sus modos de representación desde los inicios del cine hasta el presente.

Palabras clave: Jesucristo, Evangelios canónicos, Pasión de Jesús, cine bíblico, Evangelios apócrifos, iconografía.

\section{DEATH AND RESURRECTION. THE PASSION OF CHRIST \\ CONCEIVED BY THE SEVENTH ART}

\section{Abstract}

This paper tries to delve into some films related to Jesus of Nazareth, specially with those focused on his Passion, Death and Resurrection. We display an iconography analyze on how their different manners of representation have changed since the beginning of the cinema story so far.

Keywords: Jesus of Nazareth, The Canonical Gospels, Passion of the Christ, Biblical Cinema, The Apocryphal Gospels, Iconography.

Los directores se sienten incómodos con Cristo.

Muchas veces saben qué quieren hacer con Él,

Pero no saben qué normas seguir.

Sheila Johnston* 
La figura de Jesús siempre ha interesado a los artistas de todos los tiempos, y los productores cinematográficos no iban a ser menos, pero, en muchas ocasiones y dependiendo del enfoque que se les dé a determinados temas cristológicos, se han generado graves problemas entre diferentes sectores de población ${ }^{1}$. Los estudiosos proponen el año 1897 como el del comienzo de la «jesusmanía», concretamente a partir de una película rodada en París por los hermanos Lumiére, inspirada en el costumbrismo religioso de los pueblos de Bohemia y titulada La vida y la Pasión de Jesucristo (La Vie et la Passion de Jesús-Christ, Louis y Auguste Lumiére). En total son trece escenas que comienzan con el episodio de la Adoración de los Reyes Magos y finalizan con la Resurrección.

Otras voces afirman que la película donde por vez primera aparece el rostro de Jesús es en La Pasión de Cristo, rodada el mismo año (La Passion du Christ, Léar y Basile, 1897). En este sentido, y teniendo en cuenta la serie de filmes rodados ese año, podemos afirmar que en 1897 se da el pistoletazo de salida a este género cinematográfico, pues a esta primera le sigue la italiana La Pasión de Jesús (La Passione di Gesú, $1897^{2}$ ) de Luigi Topt y Ezio Cristofari, inspirada en las "pasiones vivientes» que en Semana Santa se escenifican en Italia, y que tiene como protagonista a la Bella Otero en el papel de la Virgen; en total se escenifican diez escenas rodadas coincidiendo con la semana de pasión. El mismo año en Estados Unidos se rodó Passion Play de Oberammergau (H.C. Vincent, 1897) ${ }^{3}$, recreándose en la terraza del Grand Central Palace de Nueva York los paisajes naturales de Oberammergau (Baviera $)^{4}$, donde cada diez años sus habitantes celebran el misterio pasional reproduciendo las escenas más representativas de la Pasión y Muerte del Nazareno; mientras, en Francia en 1898, Georges Méliès dirige Cristo sobre las aguas (Le Christ marchandt sur les eaux, 1898), un corto donde en veinte metros de película, y a base de fantasías y transparencias cinematográficas, se describe el momento en el que, ante el desconcierto de los apóstoles, Jesús camina sobre las aguas del lago Tiberíades 5 . Este episodio, donde Jesús muestra a los apóstoles su carácter sobrenatural, lo recogen Mateo (Mt 14, 22-23), Marcos (Mc 6, 47-51) y Juan (Jn 6, 16-21). De hecho, no se creen lo que ven y sienten miedo; Pedro intenta hacer lo mismo pero se hunde, por lo que Jesús debe rescatarlo. Según Mateo este hecho significa que Jesús es el

* Gil de Muro, E.T. (2006): Diccionario de Jesús en el cine, Burgos, Monte Carmelo. p. 381.

1 Sola Antequera, D. (2008): «La pasión de Jesús en el cine contemporáneo. La reelaboración de los Evangelios en el cine», en Piñero, A. y Gómez Segura, E.: La verdadera historia de la Pasión. Según la Investigación y el Estudio Histórico, Madrid, Edaf. pp. 235-263.

2 Esta fecha es muy discutida, pues algunos la sitúan en 1900.

3 Kinnard, R. y Davis, T. (1992): Divine Images. A History of Jesus on the Screen, N.Y., A Cita del Press Book, pp. 19-21.

${ }^{4}$ Oberammergau es un municipio del distrito de Garmisch-Partenkirchen, en el estado federado de Baviera (Alemania), en el valle del río Ammer. Tras la epidemia de peste del año 1634, sus habitantes escenifican cada diez años la Pasión de Jesús. La próxima será en el año 2020.

5 El mar de Galilea, también llamado lago Tiberíades o lago de Genesaret, tiene un cierto protagonismo en la vida pública de Jesús. Lo atraviesa en episodios narrados por Marcos (Mc 4, 35-45 y 5,21$)$ y Lucas (Lc 8, 22-25), o predica desde una barca según Marcos (Mc 4). 
Salvador de los afligidos, debiendo adorársele como Hijo de Dios (Mt 14, 28-33). Para Eduardo Gil esta corta secuencia

no es, exactamente, más que eso: el milagro flotante de Jesús. De manera que el valor que hay que conceder a este trabajo casi emblemático de Meliès es solamente ese: el milagro de Cristo parece un milagro por partida doble: el que narra el Evangelio y el que se inventa Meliès en ese corto de apenas veinte metros de película ${ }^{6}$.

No obstante, hay que señalar que, si bien es cierto que el número de películas por estas fechas es muy numeroso ${ }^{7}$, su calidad artística es bastante pobre.

A comienzos del siglo xx Olcott dirige Del pesebre a la cruz (From the Manger to the Cross, Sydney Olcott, 1913) ${ }^{8}$, donde el papel de Jesús lo interpreta Robert Henderson-Bland, rodándose en Tierra Santa durante la Semana Santa de 1912. Pese al éxito obtenido, la crítica no le acompañó, pues se la acusó de haber dado pie al restablecimiento en Inglaterra de la censura religiosa. Obviamente, este hecho no sucedió exactamente así, porque el British Board of Film Censors no se creó hasta noviembre de ese año, antes del estreno de la película, prohibiendo -entre otras cosas- que ningún desnudo aparezca en la pantalla. Y tampoco se verá a ningún Jesús. Pero lo cierto es que el número de películas rodadas a partir de esas fechas es de tal magnitud que en 1909 el papa Pío X impide a los religiosos verlas, y en 1913 prohíbe su exhibición aunque ésta se hiciera con fines didácticos, alegando la frivolidad y la libertad de la que hacen gala, entendiendo que atentan y causan confusión en los espectadores. En la misma línea de lo alegado por el pontífice a principios del siglo xx, la Iglesia y los teóricos se manifestaron en la segunda mitad del siglo XVI, tras acabar el Concilio de Trento en diciembre de 1563, prohibiendo que en los templos se exhiban determinadas iconografías religiosas no verificadas por los Evangelios canónicos, obligando a los sacerdotes a retirarlas porque pueden inducir a «error dogmático» entre los fieles. No obstante, en un alarde de cierta «libertad» y apelando a su valor didáctico, en determinadas ocasiones se las puede exhibir. Pero para el caso cinematográfico ni siquiera su valor didáctico impide que no sean visionadas.

Pese a todo, entre 1900 y 1950, el número de películas de esta temática siguió aumentando, aunque desde el punto de vista estético el resultado es bastante malo?.

${ }^{6}$ Gil de Muro, E.T., p. 35.

7 Otras películas de estos años son La Pasión de Cristo (La Passion du Christ, Eugene Pirou, 1897); Passion Play (Passion Play, Sigmund Lubin, 1898); Vida de Cristo (Vie du Christ, Leo Gaumont, 1899).

${ }^{8}$ Kinnard, R. y Davis, T. (1992), pp. 21-22.

9 De estos años son, entre otras, la francesa Passión «Buena Prensa» (Passion «Bonne presse», 1904); La Pasión de Cristo (The Passion of Christ, Ludwig Deutsch, 1905); Benhur (Sydney OlcottFranck Oakes Rose, 1907, EE. UU.); La leyenda de la cruz (La legenda della Croce, Giovanni Vitrotti, 1907); Vida, Pasión y Muerte de Nuestro Señor Jesucristo (La Vie et la Passion de Jesus Christ, Ferdinand Zecca, 1907); El beso de Judas (Le baiser de Judas, Armand Bour, 1908, Francia); Cristo en la cruz (Le Christ en Croix, Louis Feuillade, 1910, Francia); La Natividad (La Nativité, Louis Feuillade, 1910, 


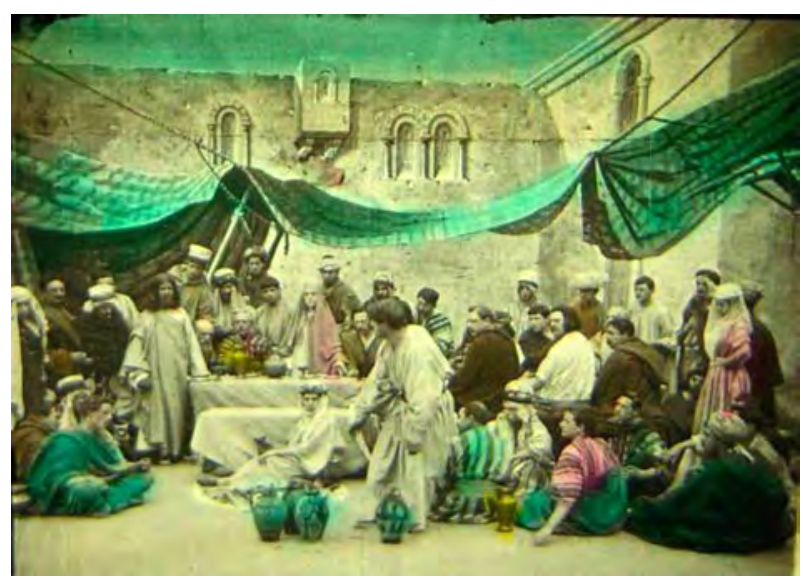

Foto 1. Vida, Pasión y Muerte de Nuestro Señor Jesucristo (La vie et la passion du Christ, Ferdinand Zecca y Lucien Nonguet, 1902).

Es el caso de Vida, pasión y muerte de Nuestro Señor Jesucristo (La vie et la passion du Christ, Ferdinand Zecca y Lucien Nonguet, 1902); comenzada en 1902, no se finalizó hasta dos años más tarde, en 1904, escenificándose en cuarenta cuadros las diferentes historias pasionistas, pero la trama y a sus protagonistas era difícil seguirlos porque desaparecían mezclados entre tantas bambalinas y telones pintados [foto 1].

Francia); Mater Dolorosa (Louis Feuillade, 1910, Francia); El dinero de Judas (Il denaro di Giuda, Luigi Maggi, 1910); Calvario (Ernesto María Pasquali, 1911, Italia); Jesús de Nazareth (André Calmettes, 1911, Francia); Judas (Il denaro de Giuda, Luigi Maggi, 1911); La Pasión de Jesús en Laino (La Passione di Gesú a Laino, 1912, Italia); Satanás (Satana: il dramma dell umanitá, 1912, Italia); El peregrino (Il pelegrino, Mario Caserini, 1912); Jesús, hijo del carpintero (La vie de Nôtre Seigneur Jesús-Christ, Maurice-André Maître,1913); La Pasión de Cristo (La Passione di Cristo, 1914); La última cena (The last supper, Lorimer Johnston, 1914, EE. UU.); Gólgota (1916, Italia); Hacia la cruz (Mod Lyset, HolgerMadsen, 1916, Suecia); Cristo (Christus, Giulio Antamoro, 1916); Intolerance (Intolerance, W.D. Griffith, 1916); Maria Magdalena (Maria di Magdala, Aldo Molinari, 1918); Restitución (Restitution, Howard Gaye, 1918, EE. UU.); Nuestro Señor Jesucristo. Bosquejo cinematográfico (Arturo Carballo, 1918, España); Redención (Redenzione, Carmine Gallone, 1918); Judas (Giuda, Febo Mari -Alfredo Rodríguez-, 1919); Hojas del diario de Satán (Blade of Satans bog, Carl Theodor Dreyer, 1919); El Cristo de Oberammergau (Der Christus von Oberammergau, Franz Seitz (también atribuida a Toni Attenberger, 1920); I.N.R.I. (Robert Wiene, 1920, Alemania); El Galileo (Der Galilaer, Dimitri Buchowetzki, 1921, Alemania); Benhur (Fred Niblo, 1925, EE. UU.); La agonía de Jerusalén (L'agonie de Jerusalen, Julián Duvivier, 1926, Francia); Rey de reyes (King of the Kings, Cecil B. de Mille, 1927, EE. UU.); Jesús de Nazareth (Jesus of Nazareth, 1912, EE. UU.); Ecce Homo (Walter Rilla, 1930, Gran Bretaña); Gólgota (Julien Duvivier, 1935, Francia); Jesús de Nazareth (José Díaz Morales, 1942, México); La pecadora de Magdala (Maria Magdalena, Miguel Contreras Torres, 1946, México); El drama de Cristo (Il dramma di Cristo, Luciano Emmer y Enrico Gras, 1948, Italia); La Pasión según San Mateo (Matthaüs-Passion, Ernst Marischka, 1949, Austria-Italia); Procesión en Lawton (The Lawton story, William Beaudine y Harold Daniela, 1949, EE. UU.); Mater Dei (Emilio Cordero, 1950, Italia). 
Posiblemente la mejor producción de este comienzo de siglo salió de los Estudios Gaumont de París; nos referimos a La vida de Cristo (La Vie de la Passion de Jesus Christ, V. Jasset y Alice Guy, 1906), inspirada en las obras del pintor James Tissot, quien en 1887 había visitado Palestina, pintando una serie de acuarelas que sirvieron de base para el filme. Para Fernández Cuenca, Jasset es uno de los realizadores franceses más inteligentes y ambiciosos de su época, superando a sus contemporáneos por

sus grandes decorados, buen vestuario, composiciones de verdadera calidad plástica, encuadres bastante atrevidos y un sentido riguroso de la acción dramática junto con una clara sinceridad religiosa ${ }^{10}$.

Unos años más tarde, en 1916, David W. Griffith rueda Intolerancia (Intolerance), donde cuenta cuatro historias de injusticias: la caida de Babilonia como fruto de la intolerancia politica (ante el ataque de Ciro II el Grande en el año 539 a.C.), la Pasión y Muerte de Cristo por la intolerancia farisaica, la noche de San Bartolomé de 1572 en París como expresión de la intolerancia religiosa y la intolerancia social que preside la dramática secuencia moderna ${ }^{11}$. Estas cuatro tramas, que va enlazando una mujer meciendo una cuna (Lilian Gish), no tuvo el éxito esperado y sufrió fuertes críticas siendo rechazada por los puritanos que luchaban contra la legitimación del alcohol. La historia que nos interesa comienza con las bodas de Caná, episodio con el que arranca la vida pública de Jesús, y termina con la crucifixión. Según explicó Griffith, cuando realizaron esta secuencia advirtieron que debian absolver a Jesús del consumo de alcohol, porque entonces estaba prohibido. Según el evangelista Juan, éste es su primer milagro público, consistente en convertir el agua en vino durante un banquete de bodas (Jn 2, 1-11) ${ }^{12}$ [foto 2].

${ }^{10}$ Fernández Cuenca, C. (1960): Cine religioso. Filmografía crítica. 1896-1959, Valladolid, Sever. p. 52.

${ }^{11}$ Idem, p. 57.

${ }^{12}$ Las bodas de Caná, Jn 2:1-11. «Al tercer día se hicieron unas bodas en Caná de Galilea; y estaba allí la madre de Jesús. Y fueron también invitados a las bodas Jesús y sus discípulos. Y faltando el vino, la madre de Jesús le dijo: No tienen vino. Jesús le dijo: ¿Qué tienes conmigo, mujer? Aún no ha venido mi hora. Su madre dijo a los que servían: Haced todo lo que os dijere. Y estaban allí seis tinajas de piedra para agua, conforme al rito de la purificación de los judíos, en cada una de las cuales cabían dos o tres cántaros. Jesús les dijo: Llenad estas tinajas de agua. Y las llenaron hasta arriba. Entonces les dijo: Sacad ahora, y llevadlo al maestresala. Y se lo llevaron. Cuando el maestresala probó el agua hecha vino, sin saber él de dónde era, aunque lo sabían los sirvientes que habían sacado el agua, llamó al esposo, y le dijo: Todo hombre sirve primero el buen vino, y cuando ya han bebido mucho, entonces el inferior; mas tú has reservado el buen vino hasta ahora. Este principio de señales hizo Jesús en Caná de Galilea, y manifestó su gloria; y sus discípulos creyeron en él. Después de esto descendieron a Caphernaum, él, su madre, sus hermanos y sus discípulos, y estuvieron allí no muchos días». 


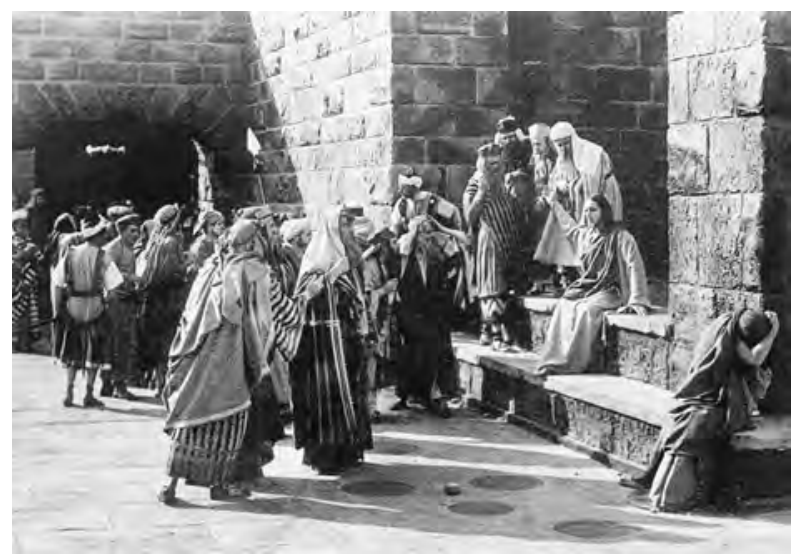

Foto 2. Intolerancia (Intolerance, David W. Griffith, 1916).

En medio quedan otras escenas como la unción de los pies por una mujer, tradición recogida por todos los evangelistas (Mt 26, 6-13; Mc 14, 3-9; Lc 7, 37-50 y Jn 12, 1-8). Todos menos Lucas sitúan el episodio en Betania. En Mateo y Marcos la mujer vierte aceite perfumado sobre la cabeza. Juan identifica a la mujer con María, la hermana de Lázaro y Marta, y unge los pies, no la cabeza, mientras que Lucas sitúa la acción en Galilea, la mujer es pecadora y echa aceite sobre la cabeza, ungiendo, lavando y besando sus pies $(\mathrm{Lc} 7,37-50)^{13}$. El resto de los episodios pasionistas parten de la subida al calvario y finalizan con la muerte en la cruz.

Durante los años 50 y 60 se rodarán películas para todos los gustos; unas francamente malas como la mexicana El mártir del Calvario (Miguel Morayta Martínez, 1952) [foto 3], en la que el papel protagonista recayó en el actor español

${ }^{13}$ Lc 7, 36-50. En aquel tiempo, un fariseo rogó a Jesús que comiera con él, y, entrando en la casa del fariseo, se puso a la mesa. Había en la ciudad una mujer pecadora pública, quien al saber que estaba comiendo en casa del fariseo, llevó un frasco de alabastro de perfume, y poniéndose detrás, a los pies de Jesús, comenzó a llorar, y con sus lágrimas le mojaba los pies y con los cabellos de su cabeza se los secaba; besaba sus pies y los ungía con el perfume. Al verlo el fariseo que le había invitado, se decía para sí: «Si éste fuera profeta, sabría quién y qué clase de mujer es la que le está tocando, pues es una pecadora». Jesús le respondió: «Simón, tengo algo que decirte». Él dijo: «Di, maestro». "Un acreedor tenía dos deudores: uno debía quinientos denarios y el otro cincuenta. Como no tenían para pagarle, perdonó a los dos. ¿Quién de ellos le amará más?». Respondió Simón: «Supongo que aquel a quien perdonó más». Él le dijo: «Has juzgado bien», y volviéndose hacia la mujer, dijo a Simón: «¿Ves a esta mujer? Entré en tu casa y no me diste agua para los pies. Ella, en cambio, ha mojado mis pies con lágrimas, y los ha secado con sus cabellos. No me diste el beso. Ella, desde que entró, no ha dejado de besarme los pies. No ungiste mi cabeza con aceite. Ella ha ungido mis pies con perfume. Por eso te digo que quedan perdonados sus muchos pecados, porque ha mostrado mucho amor. A quien poco se le perdona, poco amor muestra». Y le dijo a ella: «Tus pecados quedan perdonados». Los comensales empezaron a decirse para sí: «Quién es éste que hasta perdona los pecados?». Pero Él dijo a la mujer: «Tu fe te ha salvado. Vete en paz». 


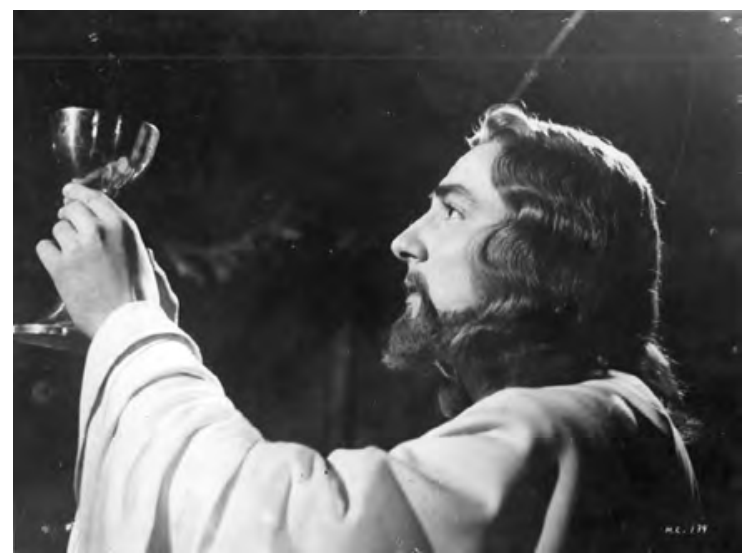

Foto 3. Enrique Rambal como Jesús en El mártir del Calvario (Miguel Morayta Martínez, 1952).

Enrique Rambal, junto a Consuelo Frank (María), Manolo Fábregas (Judas), José Baviera (Poncio Pilato) y Alicia Palacios (María Magdalena), de la que Fernández Cuenca opina que

era difícil conseguir tal acumulación de mediocridad como la que se contiene en esta lamentable y ridícula versión de los Evangelios con efectos francamente grotescos, como el Sermón de la Montańa, o tan torpes como la Ascensión final ${ }^{14}$,

y otras más curiosas como la francesa La vida de Jesús (La vié de Jesús, Marcel Gibaud, 1952), donde en ochenta minutos y basándose en cuadros de pintores de todos los tiempos como Giotto, fra Angelico, Botticelli, Van Eyck, Lucas Cranach, el Greco o Georges de la Tour, se recrean los diferentes momentos de la Pasión.

Hay otras cuyas historias completas o en parte son inventadas, y en las que casi con calzador se introducen en la trama las escenas pasionistas ${ }^{15}$. Caso notable,

${ }^{14}$ Gil de Muro, E.T. p. 113.

15 De los años 50-60 son, entre otras: El beso de Judas (Rafael Gil, 1953, España); Cristo (Margarita Alwxandre y Rafel Torrecilla, 1953, España); Yo he visto su gloria (I beheld his glory, John T. Coyle, 1953, EE. UU.); el documental Cristo entre los primitivos (Christ among the Primitives, Vincenzo Lucci Chiarissi, 1953, Italia); El hijo del hombre (Il figlio dell'uomo, Virgilio Sabel, 1954, Italia); Los lugares de la vida del Redentor (I luoghi della vita del Redentore, Rinaldo Di Favor, 1955, Italia), tres documentales sobre aquellos paisajes donde transcurrió la vida pública de Jesús; El que debe morir (Celui quidoir mourir, Jules Bassi, 1956, Francia-Italia); La Redención (La Redenzione, Vincenzo Lucci Chiarissi, 1958, Italia); El poder de la Resurreccion (The power of the Resurrection, Harold Schuster, 1958, EE. UU.); El gran pescador (The Big Fisherman, Frank Borzage, 1959, EE. UU.), cuyo argumento se basa en la novela homónima de Lloyd C. Douglas; Poncio Pilato (Ponzio Pilato, Gian Paolo Callegari, 1961, Italia); Sentado a tu derecha (Seduto alla sua destra, Valerio Zurlini, 1967, Italia); Los hechos de los Apóstoles (Atti degli Apostoli, Roberto Rossellini, 1968, Italia-Francia-Alemania-España). 


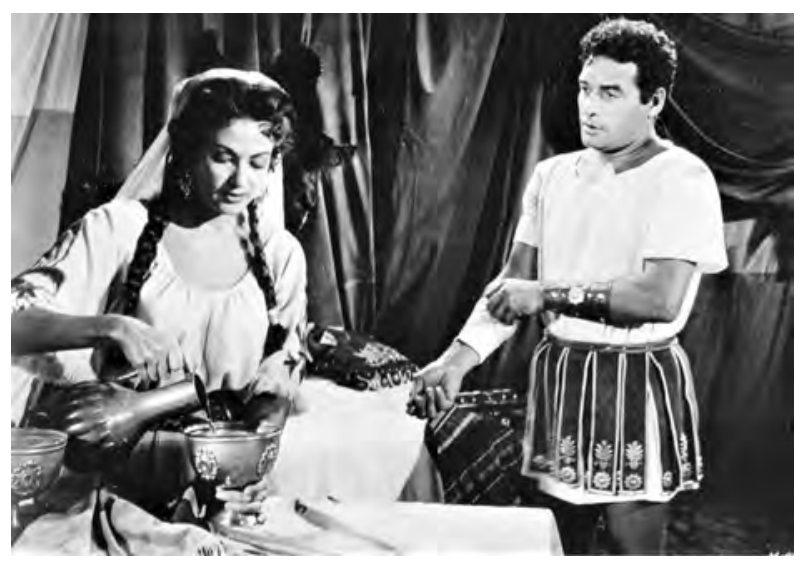

Foto 4. Ivonne de Carlo y Jorge Mistral en La espada y la cruz

(La Spada e la Croce, Carlo Ludovico Bragaglia, 1958).

por su disparatado guion, lo constituye la película italiana La espada y la cruz ( $L a$ Spada e la Croce, Carlo Ludovico Bragaglia, 1958), con un argumento completamente ficticio, hasta punto de escribirse de ella que

nunca fue razonablemente sensato inventar argumentos absolutamente despavoridos a cuenta y riesgo de la historia de Jesús o de los personajes que con Jesús vivieron una existencia decididamente excepcional y trascendente. Pero hay exageraciones y exageraciones, y las que se permite este argumento son de las que se salen de madre para meterse de hoz y coz en el apartado de los cuentos imposibles ${ }^{16}$.

Interpretada por Ivonne de Carlo en el papel de María Magdalena y Jorge Mistral en el del centurión Cayo Marcelo [foto 4], además de Mario Girotti, más adelante conocido como Terence Hill, en el papel de Lázaro. La historia comienza con la llegada a Judea de Cayo Marcelo para controlar el comportamiento del gobernador Poncio Pilato. La trama se articula en torno a la historia de amor y celos entre Cayo Marcelo, María Magdalena y Anás -suegro del sumo sacerdote Caifás- (Massimo Serato) amante de María. A María Magdalena se la hace hermana de Marta y Lázaro, e incluso también se la relaciona con Barrabás. En realidad las dos Marías más importantes de los relatos evangélicos son María Magdalena (o de Magdala) y María de Betania (a veces identificada con la anterior, pero más usualmente identificada como la hermana menor de Lázaro y Marta, amigos de Jesús). Existe una oposición entre ambas personalidades; ellas son las más cercanas a Jesús como "compañeras», de modo que la de Magdala se identifica con el arrepentimiento y simboliza

${ }^{16}$ Gil de Muro, E.T., pp. 143-144. 
la Ley y los profetas del Antiguo Testamento, mientras que la de Betania, caracterizada por el amor libremente escogido, alude al Nuevo Testamento. En medio de toda esta locura aparece Jesús de Nazaret y María cambia su actitud, abandonándolo todo para seguirle. Curiosa es la escena de la resurrección de Lázaro, pues no coincide con ningún relato evangélico. Según Juan (Jn 11, 28-38):

Habiendo dicho esto, fue y llamó a María su hermana, diciéndole en secreto: El Maestro está aquí y te llama. Ella, cuando lo oyó, se levantó de prisa y vino a él. Jesús todavía no había entrado en la aldea, sino que estaba en el lugar donde Marta le había encontrado. Entonces los judíos que estaban en casa con ella y la consolaban, cuando vieron que María se había levantado de prisa y había salido, la siguieron, diciendo: Va al sepulcro a llorar allí. María, cuando llegó a donde estaba Jesús, al verle, se postró a sus pies, diciéndole: Señor, si hubieses estado aquí, no habría muerto mi hermano. Jesús entonces, al verla llorando, y a los judíos que la acompañaban, también llorando, se estremeció en espíritu y se conmovió, y dijo: ¿Dónde le pusisteis? Le dijeron: Señor, ven y ve. Jesús lloró. Dijeron entonces los judíos: Mirad cómo le amaba. Y algunos de ellos dijeron: ¿No podía éste, que abrió los ojos al ciego, haber hecho también que Lázaro no muriera?

Y continúa Juan (Jn 11, 38-44):

Jesús, profundamente conmovido otra vez, vino al sepulcro. Era una cueva, y tenía una piedra puesta encima. Dijo Jesús: Quitad la piedra. Marta, la hermana del que había muerto, le dijo: Señor, hiede ya, porque es de cuatro días. Jesús le dijo: ¿No te he dicho que si crees, verás la gloria de Dios? Entonces quitaron la piedra de donde había sido puesto el muerto. Y Jesús, alzando los ojos a lo alto, dijo: Padre, gracias te doy por haberme oído. Yo sabía que siempre me oyes; pero lo dije por causa de la multitud que está alrededor, para que crean que tú me has enviado. Y habiendo dicho esto, clamó a gran voz: !Lázaro, ven fuera! Y el que había muerto salió, atadas las manos y los pies con vendas, y el rostro envuelto en un sudario. Jesús les dijo: Desatadle, y dejadle ir.

En la película María estaba ausente en casa de Anás, y cuando regresa a su casa le comunican que su hermano Lázaro ha muerto y lo llevan a enterrar. Al depositarlo en el sepulcro aparece Jesús, que en medio de un contraluz resplandeciente baja la escalera de la tumba, se acerca al difunto y alargando el brazo le dice que se levante. Nada que ver con lo escrito por Juan en su evangelio, pues cuando Jesús llegó Lázaro llevaba cuatro días muerto. Según las creencias judías, el alma abandonaba el cuerpo a los cuatro días de la muerte, que era cuando comenzaba la descomposición, por eso ante la respuesta de Marta, Jesús le contestó: Yo soy la Resurrección y la vida: el que cree en mi aunque muera, vivirá (Jn 11, 24-25).

Existen otras películas, como La túnica sagrada (The Robe, Henry Koster, $1953)^{17}$, donde, partiendo de un hecho real como es la túnica que vestía Jesús cuando

17 Basada en la novela homónima publicada en 1942 de Lloyd C. Douglas. 


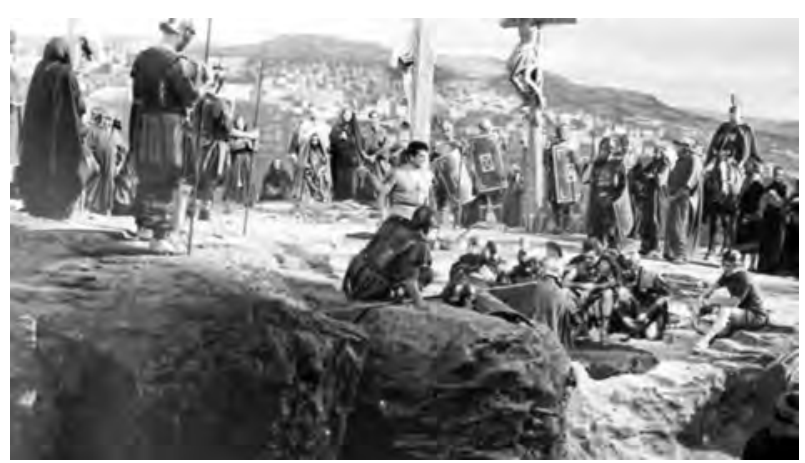

Foto 5. La túnica sagrada (The Robe, Henry Koster, 1953).

llegó al monte Gólgota, se construye toda una ficción ${ }^{18}$. El protagonista es el tribuno Marcelo Gallio (Richard Burton) y su esclavo Demetrio (Victor Mature). El tribuno ha sido desterrado de Roma y enviado a Galilea; curiosamente entran en Jerusalén en el mismo momento en el que Jesús está haciendo su entrada en la ciudad. Tras presentarse a Pilato, se le encomienda la misión de supervisar la crucifixión de Jesús, circunstancia que hará que su vida dé un vuelco cuando, al pie del madero, los soldados se juegan a los dados la túnica que aquél vestía [foto 5], y que él termina ganando. Y cuando, tras apoyarse en la cruz, su mano se cubre con la sangre que sale de las heridas de los pies del crucificado, se escucha una voz en off que dice: Padre, perdónalos porque no saben lo que hacen, que en teoría alude también al acto del propio centurión y que Jesús le ha perdonado. Cuando le pide a su esclavo que le coloque la túnica sobre los hombros para cubrirse ante la tormenta desatada tras la muerte del Nazareno, la tela parece oprimirle el cuello, como si lo asfixiara, gritándole al esclavo que lo libere de ella. A partir de ahí, su vida será una pesadilla, pues no consigue sacar de su cabeza la escena vivida. Demetrio huye llevándose la túnica y todo su afán consiste en encontrarla para destruirla, creyendo que está embrujada, y solo destruyéndola terminará «su particular calvario». Enviado a Capri, se encuentra con Diana, su prometida (Jean Simmons), y el emperador Tiberio, que le pide le informe de todo lo acontecido durante la crucifixión. Marcelo Gallio, tras narrar por espacio de dos horas lo sucedido, concluye que está «enfermo del cerebro», perdiendo el juicio cuando se puso la túnica, de modo que entiende que está embrujada, debiendo encontrarla para destruirla y curarse. A partir de ahí empieza su búsqueda, regresando a Jerusalén haciéndose pasar por un comerciante de telas, hasta que finalmente y tras muchas peripecias encuentra a Demetrio que custodiaba la túnica, conoce a Pedro en Caná, muere Tiberio, y le sucede en el trono Calígula. Convertido al cristianismo, viaja con el apóstol proclamando la fe cristiana, hasta

18 Alonso, J.J., Alonso, J, y Mastache, E. (2008): La antigua Roma en el cine, Madrid, T\&B Ed, pp. 170-179. 
que en Roma se reencuentra con Demetrio, siendo finalmente condenado a muerte junto a su esposa Diana por no renunciar a su nueva religión. Termina la película con los esposos conducidos al martirio cogidos de mano, en una especie de trono de nubes pareciendo que ascienden al Paraíso; de nuevo la Fe ha triunfado. Toda la historia es ficticia, salvo los momentos del martirio. Respecto al reparto de las ropas al pie de la $\mathrm{cruz}^{19}$, Juan dice que

los soldados, cuando crucificaron a Jesús, tomaron su ropa, haciendo cuatro partes, una para cada soldado. Y apartaron la túnica. Era una túnica sin costura, tejida toda de una pieza de arriba abajo. Y se dijeron: «No la rasguemos, sino echemos a suertes a ver a quien le toca». Así se cumplió la escritura: «Se repartieron mis ropas y echaron a suertes mi túnica» Jn 19, 23-24.

Según Javier Alonso, el episodio del reparto de los ropajes parece inventado por Juan para que se cumpla la profecía de Salmos 22, 19, que dice: Se reparten mis vestiduras y acerca de mi túnica se echan a suertes. No obstante, parece que esta práctica está documentada, apareciendo en la doctrina jurídica romana de los Digesta $48,20,6$, por lo que no hay que descartar su veracidad ${ }^{20}$.

En la trama fílmica, las vidas de Gallio, Demetrio y Jesús se entrecruzan en diferentes momentos, coincidiendo por primera vez los tres en Jerusalén, cuando se disponen a entrar en la ciudad. Jesús percibimos que pasa por delante de ellos porque la cámara gira como lo hicieran sus ojos, y lo mismo ocurre durante el trayecto de la subida al calvario, aunque el madero siempre le oculta el rostro, y en la cruz solo le vemos los pies. El Nazareno es un personaje secundario, y casi anecdótico, ya que el argumento se ha construido en torno a la túnica que vestía el día de su muerte.

En El cáliz de plata (The Silver Chalice, Victor Saville, 1954) ${ }^{21}$, se sigue la misma línea, pues la trama gira, nuevamente, en torno a un cáliz que debe cincelar un esclavo llamado Basilio (Paul Newman), por encargo del evangelista Lucas [foto 6]. La copa ha de ir decorada con las caras de Jesús y los apóstoles, y será como un relicario que contenga el cuenco usado por Jesús en la última cena. Para tal menester visita a José de Arimatea y en su casa conoce a su nieta Debora (Anna María Pierangeli), pero, faltándole el rostro del Maestro, viaja a Roma para que Pedro (Lorne Green) se lo describa, cruzándose en su camino Simón el Mago (Jack Palance), considerado a partir del escritor cristiano Justino (siglo il d.C.) como un anticristo ${ }^{22}$ y

${ }^{19}$ Los evangelistas Lucas y Juan dicen algo respecto a su vestimenta, de modo que Lucas (Lc 8, 44) afirma que vestía túnica, mientras que Juan (Jn 19, 23) solo añade que carecía de costuras y calzaba sandalias. Cfr. Alonso López, J. (2004): La última semana de Jesús, Madrid, Oberón, p. 82. La tradición cristiana refiere que la túnica había sido un regalo de María a su hijo, tejida sin costuras y muy difícil de cortar.

${ }_{20}$ Idem, p. 191.

${ }^{21}$ Esta adaptación de una novela de Thomas B. Costain supuso el debut cinematográfico de Paul Newman.

${ }^{22}$ Sus seguidores practicaban la magia como profesión y llevaban pendientes del cuello hilos de color morado y rosáceo como señal del pacto hecho con el diablo. Se dice que «estos pérfidos 


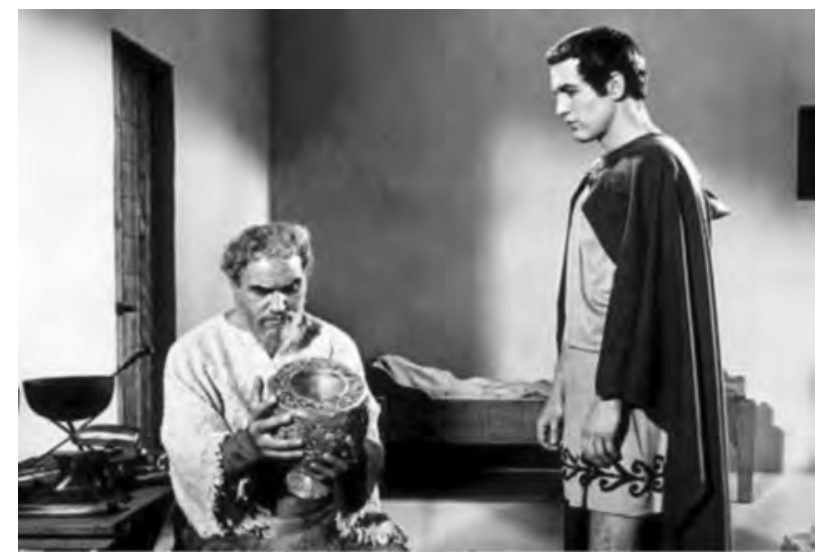

Foto 6. Paul Newman en el El cáliz de plata (The Silver Chalice, Victor Saville, 1954).

el origen de la herejía gnóstica. Le acompaña una prostituta de Tiro llamada Elena, papel que en la película interpreta Virginia Mayo, y que, según las especulaciones gnósticas, Simón consideraba una emanación divina de su propia mente ${ }^{23}$.

Respecto a Ben-Hur (William Wyler, 1959) ${ }^{24}$, en realidad es la historia de Judá y Messala; concretamente la vida del primero transcurre paralela a la pública de Jesús, quien como una sombra benéfica aparece en momentos muy concretos de su vida. Una historia de celos, amores y venganzas, en la que a Jesús solo lo vemos en un instante durante la subida al calvario, aunque antes se había producido un encuentro entre ambos, concretamente cuando Judá Ben-Hur bebe agua del cuenco que le ofrece la mano del Nazareno cuando, como esclavo, es conducido a galeras; de modo que, años más tarde, cuando aquél cae por el peso del madero subiendo al calvario, éste le devolverá el favor ofreciéndole agua. Subtitulada como «Una historia de los tiempos de Cristo", es una de las grandes superproducciones de la Metro-Goldwyn-Mayer, con cerca de trescientos escenarios, entre ellos el gigantesco circo donde se lleva a cabo la carrera de cuadrigas que enfrenta a Ben-Hur con Messala, y que termina con la muerte del segundo, realizados en los estudios romanos de Cinecittá25.

inventaron para sí mismos un evangelio, que dividieron en cuatro secciones, y lo llamaron el libro de los cuatro rincones y quicios del mundo. Ver Santos Otero, J. (1984): Los Evangelios Apócrifos. Edición critica y bilingüe, Madrid, Biblioteca de Autores Cristianos, p. 69.

${ }_{23}$ Porter, J.R. (2007): La Biblia. Las Sagradas Escrituras hebreas, los Libros Apócrifos, la llegada de Roma (Palestina en tiempos de Cristo) y el Nuevo Testamento, Barcelona, Blume, pp. 224-225.

${ }_{24}$ Adaptación de la película muda del mismo título de 1925, Ben-Hur se basa en la novela homónima de Lewis Wallace Ben-Hur, una historia de Cristo, escrita en 1880. El guion lo firma Karl Tunberg, aunque el libreto incluye aportaciones de Maxwell Anderson, S.N. Behrman, Gore Vidal y Christopher Fry.

25 Alonso, J.J., Alonso, J. y Mastache, E. (2008), pp. 181-201. 


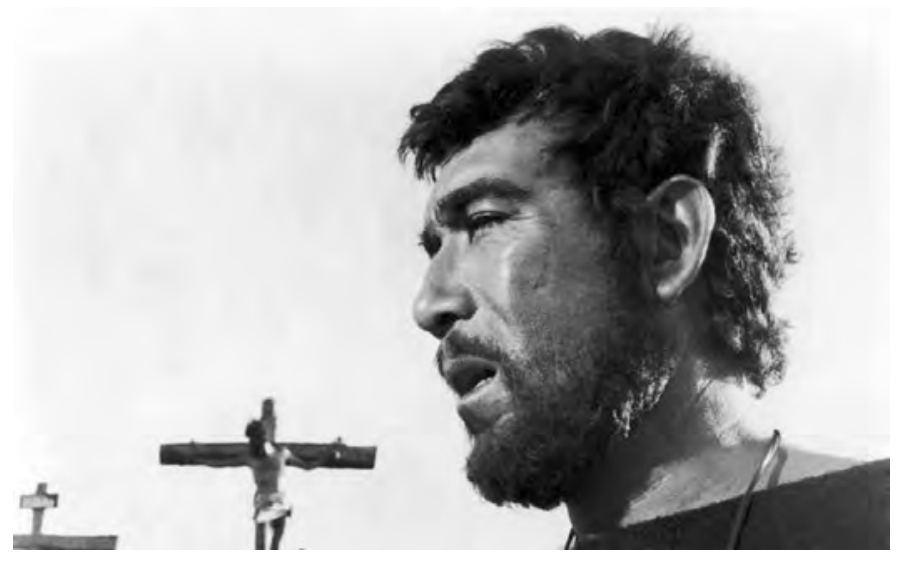

Foto 7. Anthony Quinn como Barrabás (Richard Fleischer, 1961).

Y Barrabás (Richard Fleischer, 1961) ${ }^{26}$ [foto 7] solo tiene de verdadero el eclipse solar que se produce cuando Jesús expira, pues el director lo preparó todo para que en ese día se hicieran las tomas. El resto es inventado; de hecho, son muy escasas las referencias que aportan los evangelios canónicos y los apócrifos al respecto. Según Mateo, Barrabás era un preso famoso, mientras que Marcos dice que estuvo envuelto en una revuelta y que cometió homicidio. Tanto Marcos como Lucas escriben que estaba encarcelado por insurrección (Mc 15, 7 y Lc 23, 19), por rebelarse contra el orden establecido, la Roma Imperial, lo que parece coincidir con la serie de disturbios que por aquellas fechas se dieron en Palestina, mientras que Juan solo menciona que fue un ladrón ${ }^{27}$. En realidad Barrabás es un patronímico, no un nombre; en arameo, Bar Abbas o Bar Rabbas significa Hijo de Abba o «hijo del Maestro». En algunas versiones del Evangelio de Mateo se le llama "Jesús Barabás» o "Jesús Barrabás». Según Javier Alonso, habida cuenta de que Mateo copió de Marcos el relato del juicio, se entiende que Marcos también dice que se llama Jesús, aunque pronto desapareció este nombre de los relatos evangélicos ${ }^{28}$, por lo que el episodio quizás fue incluido en la historia evangélica para reflejar el contraste entre el destino de Jesús el falso Mesias, que se libra de los sufrimientos, y Jesús el auténtico «hijo del Padre», que ha de padecer a manos de sus enemigos ${ }^{29}$. En pocas películas se le llama

26 Se basa en la novela del mismo título del sueco Par Lagerkvist.

${ }^{27}$ Calero Ruiz, C. (2012): «La cruz del otro. Barrabás y la épica bíblica en el Hollywood de los 60", Latente, Revista de Historia y estética del audiovisual, n. ${ }^{\circ}$ 8, Servicio de Publicaciones de la Universidad de La Laguna (SPULL), pp. 39-44.

${ }_{28}$ Alonso López, J. (2004): pp. 180-181. En el siglo in Orígenes de Alejandría, uno de los Padres de la Iglesia Oriental expresa sus dudas respecto al nombre, escribiendo que no conoce a ningún pecador que se llame así.

29 Porter, J.R., p. 201. 


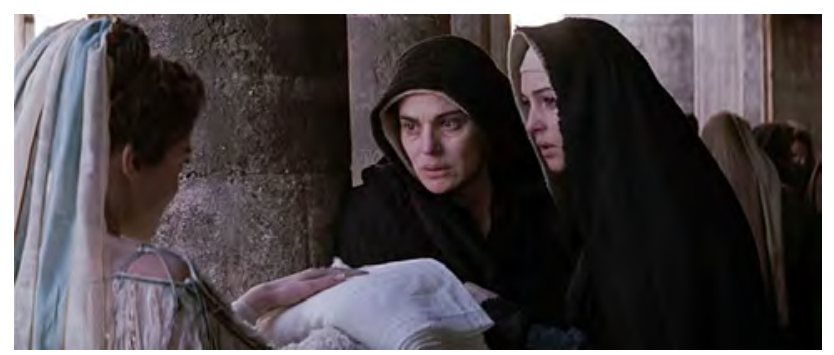

Foto 8. Claudia Prócula, María (madre de Jesús) y María Magdalena. Fotograma de la película La Passion of the Christ (Mel Gibson, 2004).

Jesús, salvo en Rey de reyes (King of kings, Nicholas Ray, 1961), cuando uno de los suyos le habla del nuevo profeta que se hace llamar Jesús como él, por lo que decide conocerlo, siguiéndolo por las calles, mezclado entre los seguidores y discípulos.

En pocas ocasiones le ponemos cara a Jesús, pues normalmente se le ve de espaldas, y cuando se le ve de frente está lo suficientemente lejos de la cámara como para que sus facciones no sean nítidas, de modo que se le intuye en un contraluz, en una sombra o se le insinúa en determinadas acciones como en el Ben-Hur de 1959, cuando una mano ofrece agua al galeote Judá, en su sombra proyectada en una pared o la de su mano posada sobre una cabeza o en un hombro -como ocurre en varias escenas de Rey de Reyes, 1961-, o en unos profundos ojos azules reflejados en el agua de la jofaina en la que Poncio Pilato lava sus manos, tras entregar a Jesús para ser crucificado (Ponzio Pilato, Gian Paolo Callegari, 1961). Concretamente esta película se centra en la llegada de Pilato a Jerusalén, su recibimiento por parte del sumo sacerdote Caifás y la sublevación del pueblo encabezada por Barrabás ante su presencia. El nuevo gobernador quiere construir un acueducto para traer el agua a la ciudad ${ }^{30}$, pero Nicodemo y José de Arimatea, como portavoces del Sanedrín, se niegan porque lo ven como un alarde más de la soberbia de Roma y por las consecuencias que traería aparejada una subida de impuestos. En la película tiene un cierto protagonismo Claudia Prócula, esposa de Pilato, que se siente conmovida por las palabras del Nazareno cuando lo oye predicar por primera vez, y que morirá aplastada bajo los muros de su palacio, tras el temblor de tierra que se sucede tras la muerte del Nazareno en la cruz [foto 8]. Se sabe poco de su vida,

30 Josefo: Los escritos esenciales (1992), Madrid, Ed. Portavoz. p. 251. El historiador judío Flavio Josefo, acerca de Pilato escribió: «... gastó dinero del tesoro sagrado para construir un acueducto para llevar agua a Jerusalén. Pero la población se encolerizó por ello, y rodearon el tribunal de Pilato cuando visitó Jerusalén. Previendo el motín, Pilato había ordenado a muchos de sus soldados que se mezclaran entre la multitud, y cuando él dio una señal, apalearon a los insultantes judíos. Aunque Pilato había ordenado que no emplearan las espadas, murió mucha gente, algunos por los palos, y otros en atropellos en la desbandada que siguió». 
salvo una pequeña mención que aparece en el Evangelio de Mateo, cuando intercede ante Pilato en favor de Jesús diciéndole:

Mientras él [Pilato] estaba sentado en el tribunal, le mandó a decir su mujer: «No te metas con ese justo, porque hoy he sufrido mucho en sueños por su causa» (Mt. 27, 19).

En las Actas de Pilatos, dentro del Evangelio Apócrifo de Nicodemo, de nuevo aparece este relato, en relación con el momento en el que Jesús entra para ser interrogado por Pilato, y cómo a su paso los bustos y los estandartes se doblegan en señal de respeto. Al ver esto Pilato tuvo miedo y quiso abandonar el tribunal, siendo en ese momento cuando su mujer le envió la misiva:

No te metas para nada con este justo, pues durante la noche he sufrido mucho por su causa. Pilato entonces llamó a todos los judíos y les dijo: ¿sabéis que mi mujer es piadosa y que propende más bien a secundaros en vuestras costumbres judías? Ellos dijeron: Sí, lo sabemos. Díjoles Pilato: Pues bien, mi mujer acaba de enviarme este recado: No te metas para nada con este justo, pues por la noche he sufrido mucho por su causa. Pero los judíos respondieron a Pilato diciendo: ¿ No te hemos dicho que es un mago? Sin duda ha enviado un sueño quimérico a tu mujer (Ac Pil, II, 1) ${ }^{31}$.

La esposa de Pilato tiene un cierto protagonismo en Rey de reyes (Nicholas Ray, 1961), donde, en compañía del centurión Lucio, acude a oír predicar a Jesús. En las Actas de Pilatos, hay una carta entre Pilatos y Herodes, en la que el procurador romano habla de ella, diciendo:

Y has de saber que Procla, mi mujer, dando crédito a las apariciones que tuvo de él cuando yo estaba a punto de mandarle crucificar por tu instigación, me dejó solo y se fue con diez soldados y Longinos, el fiel centurión, para contemplar su semblante, como si se tratara de un gran espectáculo. Y le han visto sentado en un campo de cultivo, rodeado de una gran turba y enseñando las magnificencias del Padre; de manera que todos estaban fuera de sí y llenos de admiración, [pensando] si había resucitado de entre los muertos aquél que había padecido el tormento de la crucifixión.

Y continúa:

Y mientras todos estaban observándole con gran atención, divisó a éstos y se dirigió a ellos en estos términos: «Todavía no me creéis, Procla y Longinos? ¿No eres tú por ventura el que hiciste guardia durante mi pasión y vigilaste mi sepulcro? Y tú mujer, ¿no eres la que enviaste a tu esposo una misiva acerca de mí?» [...]

${ }^{31}$ Algunos historiadores sostienen que este mensaje nunca ocurrió, sino que se introdujo para beneficiar la imagen del procurador, especialmente tras convertirse el cristianismo en religión oficial del Imperio, a comienzos del siglo iv. 


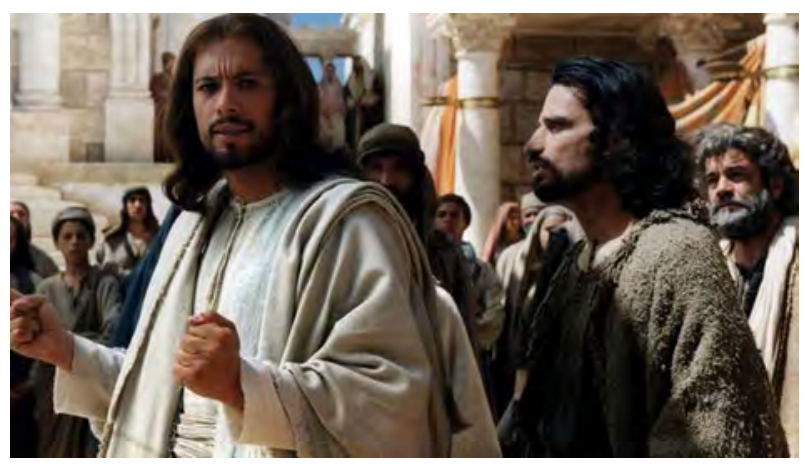

Foto 9. Enrico Lo Verso como Judas (Judas, Raffaelle Mertes, 2001).

Al oírle decir tales cosas, tanto mi mujer, Procla, como el centurión que tuvo a su cargo la ejecución de Jesús, como los soldados que habían ido en su compañía, se pusieron a llorar llenos de aflicción. Yo, a mi vez, después de oírlas, se las referí a mis grandes comisarios y compañeros de milicia; estos llenos de aflicción y ponderando el mal que habían hecho contra Jesús, se pusieron a llorar durante el día; y asimismo yo, compartiendo el dolor de mi mujer, estoy entregado al ayuno y duermo sobre la tierra (Ac Pil, Carta de Pilato a Herodes) ${ }^{32}$.

También Judas Iscariote tiene un papel relevante, y desde un principio se le presenta como un personaje atormentado por las palabras que resuenan una y otra vez en su cabeza, pronunciadas por su Maestro en la última cena: uno de ustedes que está aqui comiendo conmigo me traicionará, y al que la mirada de profundos ojos azules persigue por toda la película.

Este Judas es muy diferente al interpretado por Enrico Lo Verso en la película Judas (Judas, Raffaelle Mertes, 2001) [foto 9], donde el apóstol se nos muestra en una faceta desconocida, cual es la relación con su familia, el ambiente de riqueza en el que viven sus padres y los motivos que le llevaron a traicionar a su Maestro ${ }^{33}$. El intento de asesinato de Pilato es el que hace que sus planes se tuerzan y decida salvar a su familia, ya que Sara, su prometida, le comunica que han arrestado a su hermano Dimas y no tiene dinero para liberarlo, pues necesita treinta monedas de plata. Judas se niega a entregarle el dinero, pues entiende que pertenece a todos los discípulos; lo que no sabe es que Sara ha mentido, pues el dinero en realidad lo necesita para entregarlo a Gestas, a su hermano Dimas y a Barrabás para que sobornen a los guardias de palacio y puedan matar a Pilato.

32 Santos Otero, A. (1984): Los Evangelios Apócrifos, Madrid, Biblioteca de Autores Cristianos, pp. 485-487

${ }_{33}$ La película forma parte de una colección titulada Amici di Gesú, que pretende recrear la vida de aquellos personajes más cercanos a Jesús. 
La crítica acusó a la película de falta de fidelidad con los Evangelios, y especialmente por mostrar a Judas en su faceta humana y no como un traidor. La película comienza con la entrada de Jesús en Jerusalén, papel interpretado por Danny Quinn, y la preocupación de Pilato y del tribuno romano Veturius, temiendo que el pueblo se subleve, por lo que decide arrestarlo. Entretanto Judas cree que tras el jubiloso recibimiento que el pueblo le ha dado a Jesús a su llegada, lo nombrarán rey y él gozará de mayor protagonismo, pero el intento de asesinato de Pilato tuerce sus aspiraciones. Especialmente cuando al día siguiente observa cómo Jesús expulsa a los mercaderes del templo, ganándose la ira de los sacerdotes; este comportamiento ahora lo ha convertido a sus ojos en un enemigo, de modo que finalmente decide entregarle la bolsa con las treinta monedas a Sara, instante que es captado magistralmente por la cámara, en un primer plano; el gesto claramente alude a su traición -aunque no se haya representado al modo tradicional-, frente al sumo sacerdote Caifás.

Desde el momento en el que el cine decidió a mostrarnos el rostro de Jesús, su aspecto físico se repite en todos los filmes, salvo alguna excepción ${ }^{34}$. Las artes plásticas a lo largo de los siglos nos lo han presentado, generalmente, de cuerpo alto y delgado, rasgos occidentales, con barba y pelo largo castańo o rubio, y vestido con una túnica ${ }^{35}$. No obstante, algunos directores, especialmente en las primeras películas de la Pasión, lo han representado a la manera bizantina, como un hombre serio y maduro, de cabello largo y oscuro, y ojos negros. Tal es el caso de The Passion Play (Sigmund Lubin, 1898) y Del pesebre a la cruz (From de manger to the Cross, Sydney Olcott, 1912), donde el papel protagonista lo interpreta en el actor inglés Robert Herdensson, o Bosquejo cinematográfico (Arturo Carballo, 1918), película española protagonizada por Salvador José Marí en el papel de Jesús, entre otras. Esta fórmula se mantendrá hasta buena parte de los años 50 y 60. En las décadas siguientes, Jesús parece modernizarse, rejuvenece y su rostro es más clásico, caso de Jesucristo Superstar (Jesus Christ Superstar, Norman Jewison, 1973), interpretado por Ted Neely; Jesús de Nazareth (Gesú di Nazareth, Franco Zeffirelli, 1977), con Robert Powell; incluso Jim Caveziel en La Pasion (The Passion of the Christ, Mel Gibson, 2004), cuyo rostro recuerda al autorretrato de Caravaggio en el Santo entierro.

El cine ha hecho suyas muchas de estas tipologías, sumándole una inquietante mirada de profundos ojos azules. Jesús lo miró y lo amó, de esta manera explica el evangelista Marcos cómo es su mirada (Mc 10, 21), refrendada en varios filmes. En El beso de Judas (Rafael Gil, 1954) clava su vista en el ladrón cuando lleva la cruz camino del calvario, hasta el punto de afirmar aquél: Tú no sabes cómo mira ese hombre. También Judas queda petrificado cuando Jesús lo mira después de besarlo. Lo mismo le ocurre a Demetrio en La túnica sagrada (The robe, Henry Koster, 1953), quien al verlo pasar ante él, llegando a Jerusalén llega a afirmar: Solo sus ojos habla-

${ }^{34}$ Claveras, M. (2010): La Pasión de Cristo en el cine, Madrid, Ed. Encuentro, pp. 167- 178.

35 Eslava Galán, J. (2016): La madre del cordero. Curiosidades y secretos de la simbología cristiana, Barcelona, Planeta, pp. 71-74. 

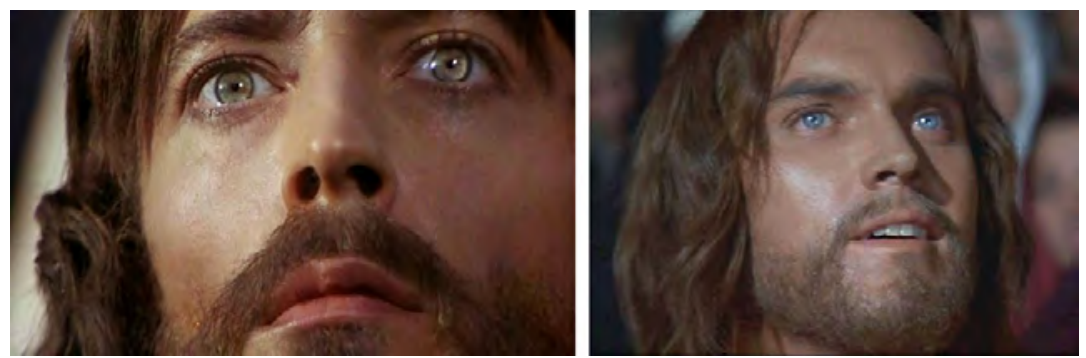

Foto 10. Robert Powell y Jeffrey Hunter.

ron... Creo que Él desea que yo le siga. O la escena de Ben-Hur (William Wyler, 1959), en el momento en el que un soldado impide que le den de beber. Y por supuesto los ojos de Robert Powell en Jesús de Nazareth (Gesú di Nazareth, Franco Zeffirelli, 1977) o de Jeffrey Hunter en Rey de Reyes (King of Kings, Nicholas Ray, 1961) ${ }^{36}$, que traspasan la pantalla [foto 10].

A veces viste una túnica casi transparente o muy blanca para que se haga visible entremezclado con la multitud de seguidores pero, sobre todo, que se intuya su presencia aun cuando no esté presente. Concretamente en la película de Zeffirelli, la comunicación de los personajes a través de las miradas es lo que más llama la atención; de hecho, creemos que se abusa de esos primeros planos. Su director cuando comenzó a rodarla declaró que quería presentar a un Jesús humano y desmitificador, pues decía que Cristo es un hombre fuerte, un hombre importante, un hombre decidido. Un hombre serio. Muy serio, a diferencia de los que aparecen en Godspell (David Greene, 1973) o en Jesucristo Superstar (Jesus Christ Superstar, Norman Jewison, 1973), que le parecen Cristos cretinos y enloquecidos, sin conciencia de su propio destino, tan desorientado como los verdugos de pega que acabarán por colgarlo de una $\mathrm{cruz}^{37}$.

En otras películas lo vemos, y no solo se oye su voz, caso de Gólgota (Julien Duvivier, 1935), interpretado por Robert Le Vigan; La túnica sagrada (The robe, Henry Koster, 1953); o Barrabás (Barabbas, Richard Fleischer, 1961), donde el papel de Jesús lo interpreta Rocco Roy Mangano, entre otros.

Respecto a su vestimenta, los evangelistas han aportado algún dato, aunque insignificante, de modo que Pablo, en su Carta a los filipenses (Flp 2, 7), dice que era como cualquier hombre, y también sus gestos, ańadiendo Mateo que solía llevar un vestido de lana sujeto con cinturón del que pendía una bolsa (Mt 10, 9) ${ }^{38}$. La película de Nicholas Ray es interesante porque enfatiza las penetrantes miradas, las cura-

36 Ya existía una película anterior con el mismo título, realizada por Paramount Pictures, Rey de Reyes, estrenada en 1927 y dirigida por Cecil B. DeMille.

37 Gil de Muro, E.T., p. 215.

38 Alonso López, J. (2004), p. 82. 
ciones con la sombra de su mano, o el efecto final -en este caso concreto-, donde la sombra de su cuerpo y las redes de pesca situadas sobre la arena de la playa dibujan una cruz. Concretamente en la escena de la resurrección el guion parece ceñirse al Evangelio de Juan, en el sentido de que solo se le aparece a María Magdalena (Jn $20,1-2)^{39}$, a quien los evangelistas no dan crédito, pensando que sufre alucinaciones.

Al respecto, ningún evangelista da un registro definitivo de la Resurrección de Jesús, aunque convergen en cuatro puntos:

- Corrimiento de la piedra que cerraba la tumba.

- Vinculación del "primer día de la semana» con la tradición de la tumba vacía y la visita de las mujeres.

- La elección de aparecerse primero a las mujeres (o a una mujer), encargándole a ella o ellas que lo comunique (n) a los discípulos, incluyendo a Pedro y a los otros apóstoles.

- La importancia de María Magdalena.

En la película de Giulio Base En busca de la tumba de Cristo (L'Inchiesta, The Inquiry, 2006), Tiberio (Max von Sydow) envía al tribuno Tito Valerio Tauro (Daniele Liotti) a Jerusalén a buscar a Jesús, o al menos su tumba, y certificar si realmente ha resucitado como sus seguidores afirman. A lo largo de la película se recurre al flashback, que altera la secuencia cronológica de la historia, conectando momentos distintos y trasladando la acción al pasado. Es el caso del momento en el que el tribuno interroga a Pilato (Hristo Shopov) sobre lo ocurrido, y si bien éste alega no saber nada, un flashback nos traslada al pasado, donde en el mismo escenario Pilato tres años antes había interrogado a Jesús. En otro momento visita el lugar de la crucifixión acompañado primero por un soldado y luego por Longinos, el centurión que clavó la lanza en el costado para certificar que Cristo había muerto, y de nuevo un flashback nos retrotrae al instante en el que este hecho se produjo y lo que supuso para el centurión ese trágico momento visible en su desencajado rostro.

El gobernador intenta impedir por todos los medios que la investigación del tribuno fructifique, pero no puede evitar que los acontecimientos sigan su curso y que el enviado de Tiberio se vea involucrado en un laberinto de pasiones y fe. En su búsqueda conoce a Miriam (Tabita, Mónica Cruz), que le indica que vaya a Betania a la casa de Lázaro, pues él puede serle útil. Cuando llega, la casa está abandonada y Taurus será víctima de un engaño por parte de los emisarios de Pilato. Finalmente, después de varias vicisitudes marcha a Galilea y conoce a María, la madre de Jesús, y a Pedro, pidiéndole que le acompañe a Jerusalén para curar a Tabita, a la que su padre ha intentado matar. Por último Pedro resucita a la joven y el tribuno se convierte al cristianismo, enviándole una carta a Tiberio, en la que le comunica, entre otras cosas, lo que ha visto y oído, afirmando que la palabra de Jesús tiene el

${ }^{39}$ Alonso López, J. (2017): La Resurrección. De hombre a Dios, Madrid, Arzalia ed, pp. 124-131. 
poder de cambiar al mundo. Le insiste que es su última carta como tribuno y exsoldado romano, pidiéndole que a partir ahora no lo busquen. Tiberio decide declarar oficial la nueva religión y hacerlo ante el senado de Roma, pero será asesinado por Calígula, que se proclama nuevo emperador, ordenando destruir todos los documentos y firmando una sentencia de muerte contra el tribuno. La historia, como no podía ser menos, tendrá final feliz, ya que éste se ha convertido al cristianismo, se ha casado con Tabita y vive en Judea. En este caso la historia real y la ficción se dan la mano en esta coproducción europea, remake de la película Una historia que comenzó hace 2000 años (L'Inchiesta, Damiano Damiani, 1986), protagonizada por Keith Carradine y Harvey Keitel.

El papel de este tribuno nos recuerda al del centurión Lucio (Ron Randell) en el Rey de reyes de Nicholas Ray, un personaje ficticio, a través del cual vamos hilando las diferentes historias. Aparece por primera vez cuando Herodes el Grande le pide degollar a los niños recién nacidos en Belén ${ }^{40}$, a lo que se niega, pero tiene que cumplir la orden del rey. Pasados doce años, visita Nazaret, avisando a la población que deben empadronarse; al preguntarle a María por la edad de su hijo, ésta le contesta que tiene doce años, advirtiéndole que no está empadronado; y al instante se percata de quién puede ser, recordando el episodio de la matanza ordenada por Herodes, pero lo pasa por alto. Pasados veinte ańos llega a Galilea Poncio Pilato, siendo recibido por Herodes Antipas, viendo a Juan el bautista bautizando en el río Jordán. Cuando el bautista es apresado, Herodes ordena a Lucio que lo encierre en una mazmorra. Jesús visita al bautista en su cautiverio y es Lucio el encargado de llevarlo; reconociéndolo le dice que en su momento su madre le había prestado un favor y ahora él se lo devuelve dejándole ver al bautista. Más tarde Lucio les refiere a Pilato y a Herodes los milagros de Jesús: las curaciones, la cena en casa del fariseo y el perdón de Magdalena, la multiplicación de los panes y los peces, Jesús caminando sobre las aguas del lago Tiberíades, y cómo tras levantarse una tormenta éste la calmó. También será él a quien el bautista le encargue encontrar a Jesús y preguntarle si realmente es el Mesías, y tras oír una voz en off que lo confirma, le libera de las esposas. Finalmente lo vemos siguiendo a Jesús en sus sermones, encontrándose con Claudia Prócula, la esposa de Pilato, presuponiéndose que ambos se convirtieron a la nueva religión.

Parecidos efectos acontecen en La historia más grande jamás contada (The Greatest Store Ever Told, George Stevens, 1965) ${ }^{41}$, donde se narra la historia completa desde el nacimiento de Jesús en Belén hasta la resurrección, plagada de un

${ }^{40}$ La tradición de la Matanza de los Inocentes, según Javier Alonso, busca explicar la profecía de Jeremías 31, 15: Una voz se oyó en Ramá, un llanto y un gran lamento: Raquel llorando a sus hijos. ¡Y no quería consolarse, porque ya no existen! De modo que su inclusión en el Nuevo Testamento identifica a Raquel con Belén, y los niños por los que llora, los asesinados por orden de Herodes el Grande. Según el mismo autor, esta historia no tiene ningún viso de realidad. Tan solo se debería aceptar como histórico el hecho de que Jesús de Nazaret nació durante los últimos años de reinado de Herodes. Cfr. Alonso López, J. (1998): Herodes El Grande, Madrid, Alderabán, p. 157.

${ }^{41}$ Inspirada en la novela homónima de Fulton Quinn. 

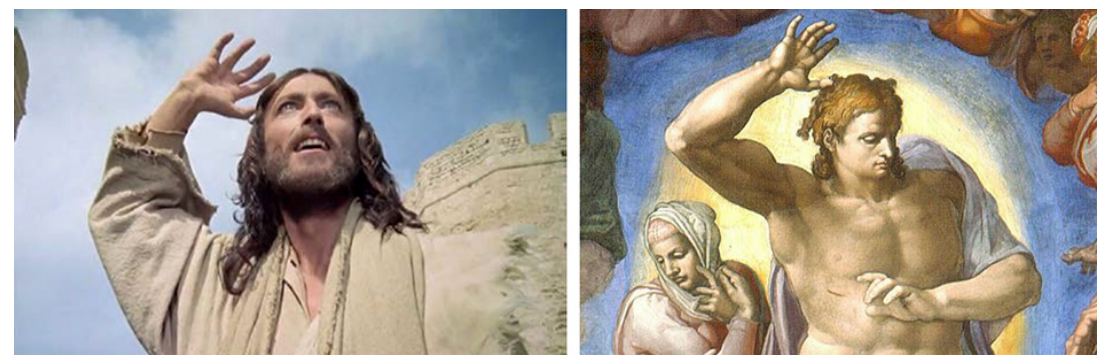

Foto 11. Robert Powell en Jesús de Nazaret (Jesus of Nazaret, Franco Zeffirelli, 1977) y Juicio Final, Miguel Ángel (det.).

reparto estelar como Max von Sydow en el papel de Jesús, Charlton Heston como Juan el Bautista o Telly Savalas como Poncio Pilato. Esta superproducción pretendía convertirse en la película definitiva sobre la figura de Jesucristo, pero cayó bajo el peso de sus propias pretensiones. Los guionistas, por un afán de recrear el mayor número posible de escenas y pasajes evangélicos, mezclaron libremente numerosos textos, de modo que el argumento está lleno de «excesivas» licencias narrativas, por lo que la película fue muy cuestionada.

Pero en ninguno de estos filmes, ni siquiera en Jesús de Nazaret (Jesus of Nazaret, Franco Zeffirelli, 1977), se abusa de la violencia durante las escenas martirológicas, a pesar de la crudeza de la crucifixión. Por el contrario, en el filme de Mel Gibson (La Passion of the Christ, 2004), la sangre traspasa la pantalla e inunda las salas cinematográficas ${ }^{42}$. Zeffirelli optó por descubrir la humanidad del hombre partiendo de sus conflictos internos, con acciones muy dramáticas, recurriendo a primeros planos. No se abusa de los efectos especiales, ni de la violencia, ni se ańaden escenas gratuitas como hizo Gibson, pese a la fuerte carga emocional que se refleja en los rostros del protagonista, que, en connivencia con el espectador, los hace partícipes de su particular procesión interna, para dejarnos su personal versión del calvario. Sólo en alguna ocasión -como en la escena de la expulsión de los mercaderes del templo- se nos muestra a un Jesús justiciero y amenazador, recordándonos con ese gesto del brazo alzado a su homónimo del Juicio Final de Miguel Ángel en la Capilla Sixtina (1537 y 1541$)^{43}$ [foto 11].

Se supone que Zeffirelli consultó los textos sagrados para saber qué quería hacer, pero Gibson, si bien alega que utilizó los Evangelios, su principal fuente

42 Calero Ruiz, C. (2005): «El Teatro de las emociones. Trento, Mel Gibson y su Pasión de Cristo", Latente. Revista de Historia y Estética del Audiovisual, n. ${ }^{\circ}$ 3, Servicio de Publicaciones de la Universidad de La Laguna (SPULL), pp. 101-110.

43 Blunt, A. (1990): «El Concilio de Trento y el arte religioso», en Teoría de las artes en Italia. 1450-1600, Madrid, Cátedra, pp. 115-141. 

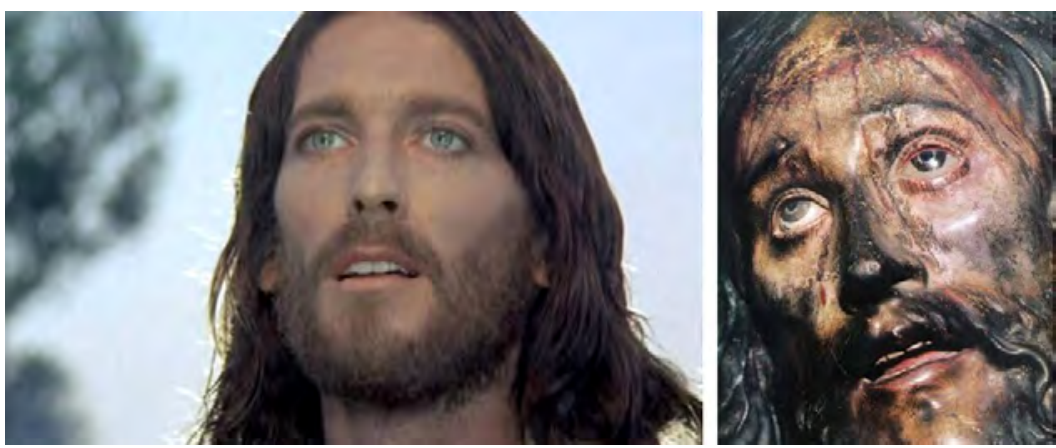

Foto 12. Robert Powell en Jesús de Nazaret (Jesus of Nazaret, Franco Zeffirelli, 1977). El Cristo de la Expiración, el Cachorro de Triana (det). Francisco Ruiz Gijón, 1682.

le vino de los escritos de la visionaria alemana Ana Catalina Emmerich ${ }^{44}$. Es cierto que Zeffirelli introduce algunas ideas de cosecha propia porque opinaba que en los momentos de mayor carga emocional era mejor intuir, pero su visión de los Evangelios es muy subjetiva. Quiere atenerse al máximo a lo narrado por los evangelistas, pero es complicado porque los Evangelios Sinópticos de Marcos, Mateo y Lucas son muy parecidos, hasta el punto de pensarse que los dos últimos se basaron en el primero ${ }^{45}$ y en otras fuentes desconocidas, que -al parecer- pudieran ser los propios dichos de Jesús. A ello hay que sumar que el Evangelio de Juan es complicado de interpretar en muchos puntos, siendo difícil trasladar lo que cuenta a la pantalla. A nivel general hay datos extraídos de los Evangelios que son discutibles, pero también muchos episodios de difícil interpretación.

Y, puesto que hay una verdadera descripción física de Cristo, de la que existen opiniones divergentes, se ha construido una imagen lo más cercana posible, gracias a los escritos de los místicos y a los artistas. Zeffirelli barajó los nombres de varios actores (Dustin Hoffman, Al Pacino) para encarnar a su protagonista antes de decantarse por Robert Powell. Quizás en su afán por dar con el modelo perfecto viera obras -esculpidas o pintadas- del Barroco español, impactándole uno de los crucificados más naturalistas del Setecientos hispalense, el del Patrocinio de Triana, el Cachorro, dado el parecido de ambos: rostro delgado con pómulos hundidos, nariz afilada, labios finos y pupilas muy expresivas ${ }^{46}$ [foto 12]. Pero en el filme hay otras escenas como la de la mazmorra donde está encarcelado el Bautista, cuya iluminación nos recuerda al fresco de La liberación de San Pedro pintado por Rafael San-

${ }_{44}$ Cfr. Emmerick, A.C. (2012): Visiones y revelaciones completas, Madrid, Ciudadelalibros. Emmerick, A.C. (2004): La amarga pasión de Cristo, Barcelona, Planeta.

45 Alonso López, J. (2017), pp. 91-94.

46 Hermosilla Molina, A. (2000), pp. 188-193. 

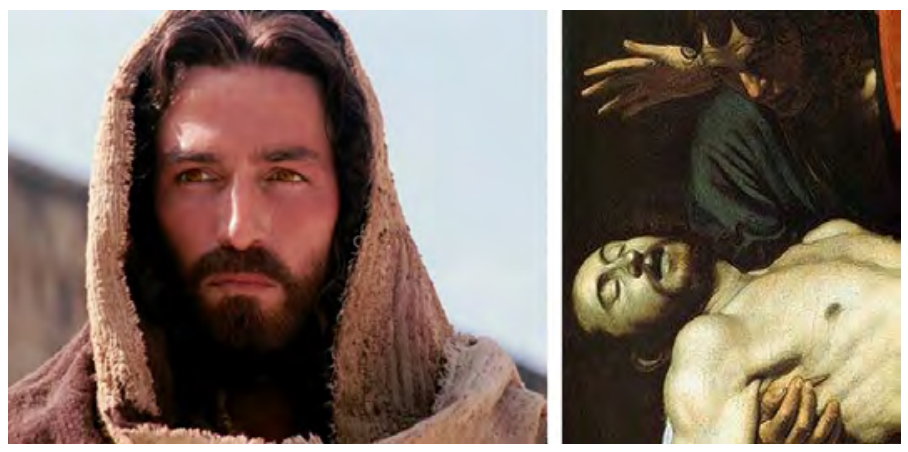

Foto 13. Jim Caveziel (La Passion of the Christ, Mel Gibson, 2004) y Santo Entierro, Caravaggio (1602-1603) (det).

zio en 1514 en la Estancia de Heliodoro (Vaticano), tal y como aparece narrada en Hechos de los Apóstoles 12, 7-10.

Según la Iglesia católica, su éxito se basó en su reverente concepción del personaje, donde en todo momento la divinidad es preservada y comunicada. Desde el punto de vista artístico es una película plana, en absoluto crítica porque no hace una reflexión sobre el personaje, y muy larga, porque simplemente se limita a enseñar todos los pasajes del Nuevo Testamento ${ }^{47}$. Gibson por su parte llega a afirmar que estudió la obra de Caravaggio, en quien se inspiró. Desde luego, su película es lo más alejado de Caravaggio, pues el maestro lombardo nunca pintó escenas tan sádicas, lo que solo viene a corroborar su absoluto desconocimiento de su producción artística, al margen de que el rostro de su protagonista -Jim Caveziel- nos recuerde al autorretrato del pintor en su Santo Entierro, pintado entre 1602 y 1604 [foto 13].

La imagen del Jesús de Zeffirelli choca con la que Pasolini nos mostró en 1964 cuando rodó el Evangelio según Mateo (Il Vangelo secondo Matteo, Pier Paolo Pasolini), donde el papel protagonista lo interpretó el periodista español Enrique Irazoqui; un desconocido para el gran público, escogido por el director para mostrar una imagen más terrenal, más humana y creíble en el aspecto físico ${ }^{48}$ [foto 14], aunque no se correspondiera con el tipo racial semita. De nuevo se narra su vida desde el nacimiento hasta la resurrección, y supuestamente los diálogos derivan del Evangelio de San Mateo de ahí su título. Mel Gibson -por el contrario- afirma que su mejor material son los Evangelios, pero su guion sigue casi al pie de la letra las visio-

47 Rodada en Marruecos y Túnez, fue alabada por la Iglesia católica italiana, pese a que los puritanos norteamericanos la rechazaron por presentar a un Jesús demasiado humano. La izquierda la calificó de kitsch, estéticamente de mal gusto. Y el diario socialista italiano La República dijo que era una larga y coloreada lección de catecismo, de aquéllas que se daba a los muchachos en las parroquias de hace treinta años, y nos habrá costado a los contribuyentes italianos millares de liras.

48 Sola Antequera, D. (2008), p. 255. 


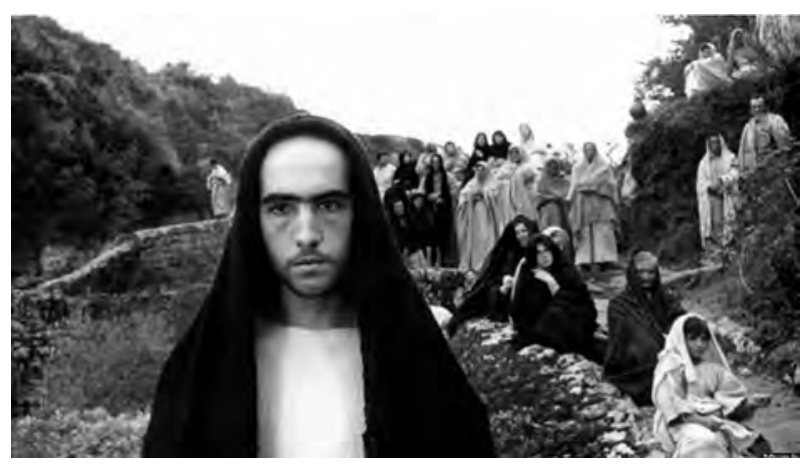

Foto 14. Enrique Irazoqui en el Evangelio según Mateo (Il Vangelo secondo Matteo, Pier Paolo Pasolini, 1964).

nes relatadas por la monja Ana Catalina Emmerich (1774-1824), añadiendo que quería darle a su personaje una carga de humanidad, presentándolo como un hombre de carne y hueso, tal y como Emmerich lo percibe en sus visiones.

En su afán por recrear lo que supuestamente ocurrió en sus últimas horas de vida, recurre a todo tipo de efectos gratuitos para empatizar con el espectador. En palabras de R. Gubern, el barroquismo de la pintura religiosa del XVII se degrada a kitsch en el cine religioso del siglo XX, y, de hecho, el único sostén de la película es la insufrible sesión de tortura durante la flagelación. Gibson, consciente de la atracción que para los espectadores tienen este tipo de escenas-sadismo creyente-, se recrea con espeluznantes primeros planos que se hacen interminables, haciendo que los espectadores sientan en carne propia el suplicio, consiguiendo que parezca que la sangre impacte en sus caras y se desparrame por toda la sala cinematográfica. Hay, no obstante, algunos momentos intensos, como aquél en el que la Virgen y otras mujeres intuyen desde otra estancia el suplicio al que lo están sometiendo, y que Emmerich describe minuciosamente, calcándolo Gibson al pie de la letra:

Vi a la Santísima Virgen en trance continuo durante la flagelación del nuestro divino Redentor. Ella vio y sufrió con un amor y un dolor indecibles todo lo que sufría su Hijo. Muchas veces salían de su boca leves quejidos, y sus ojos estaban anegados en lágrimas. Estaba cubierta de un velo y tendida en los brazos de María de Helí, su hermana mayor, que era ya vieja y se parecía mucho a Ana, su madre; María de Cleofás, hija de María de Helí, estaba también con ella. Las amigas de María y de Jesús estaban temblando de dolor y de inquietud, rodeando a la Virgen llorando a la espera de la sentencia de muerte. María llevaba un vestido largo azul parcialmente cubierto por una capa de lana blanca y un velo de un color blanco amarillento. Magdalena estaba pálida y abatida por el dolor. Tenía los cabellos en desorden bajo su velo. Cuando Jesús, después de la flagelación, cayó al pie de la columna, vi a Claudia Procla, mujer de Pilato, enviar a la Madre de Dios grandes piezas de tela [...]. Habiendo vuelto en sí, María vio a su Hijo, todo desgarrado, conducido por los soldados; Él se limpió los ojos llenos de sangre para mirar a su 


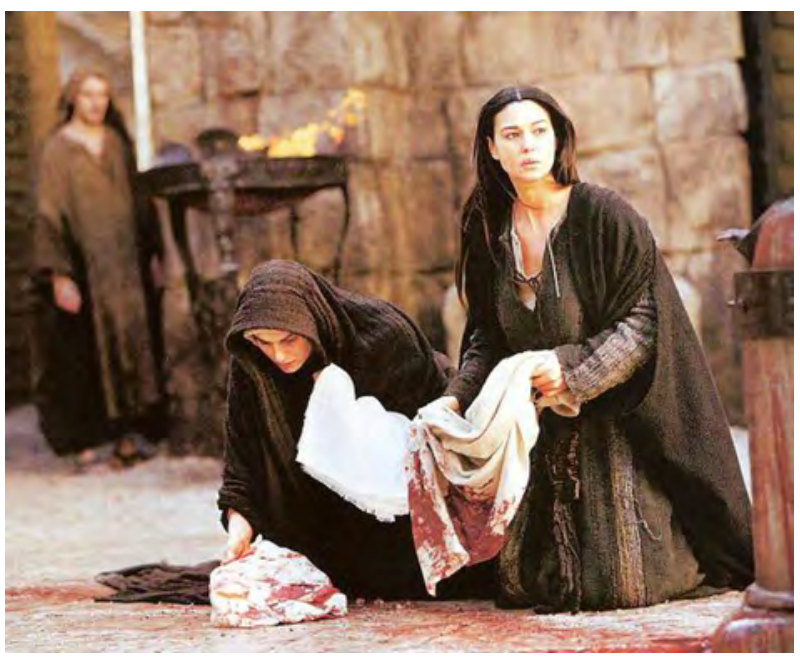

Foto 15. María (Maia Morgestern) y María Magdalena (Mónica Bellucci). (La Passion of the Christ, Mel Gibson, 2004).

Madre. Ella extendió las manos hacia Él, y siguió con los ojos las huellas ensangrentadas de sus pies. Habiéndose apartado la muchedumbre, María y Magdalena se acercaron al sitio en donde Jesús había sido azotado. Escondidas por las otras santas mujeres y por otras personas bien intencionadas que las rodeaban, se agacharon cerca de la columna y limpiaron por todas partes la Sangre sagrada de Jesús con los lienzos que Claudia Procla había mandado. Juan estaba entonces con las santas mujeres, que eran veinte [...]. Eran las nueve de la mańana cuando se acabó la flagelación ${ }^{49}$ [foto 15].

Las normas de la flagelación en el pueblo judío están dictadas en el Deuteronomio $^{50}$, pero la romana difiere notablemente de la hebrea. Para los romanos no hay límites en el número de golpes, la única condición es que el condenado no muera a consecuencia de los latigazos, de modo que se pueda continuar el suplicio en la crucifixión. A lo largo del discurso fílmico se advierten otras muchas escenas contra-

49 Emmerich, A.C. (2004). pp. 143-144.

${ }^{50}$ La flagelación era el preámbulo legal de toda condena a muerte. El número de golpes permitido, con vergas o látigos, era de cuarenta. Los fariseos lo reducen a treinta y nueve repartidos en trece azotes en el tórax y trece en cada lado de la espalda. Cuando usaban el látigo de tres cuerdas, sólo se aplicaban trece golpes. En el Derecho Romano, la flagelación se aplicaba como complemento de una sentencia, pero a veces era tan cruel que podía acabar con la vida del reo. Por ese motivo el Talmud hebraico ordenaba que se le hiciera un examen médico al condenado para saber si era capaz de soportarla. Ver Hermosilla Molina, A. (2000): La Pasión de Cristo vista por un médico (3. ${ }^{a}$ ed.). Sevilla: Guadalquivir. pp. 47-52. 
rias al hecho evangélico, pues en la resurrección nos muestra a Jesús en la soledad de su tumba, sin testigos. El kairos es mínimo si lo comparamos con la escena de la flagelación; un "auténtico suplicio» desde el punto de vista contemplativo. Pese a que hay un plano de Jesús resucitado mostrando las llagas de las manos, confirmándose una continuidad discontinua entre crucifixión y resurrección, no aparecen las mujeres que según Marcos, Mateo y Lucas acudieron aquel día al sepulcro, pues Juan solo menciona a María Magdalena ${ }^{51}$, ni el encuentro que Jesús tuvo con sus seguidores más cercanos, que constatan su resurrección, y que estaban escondidos por miedo a ser apresados. Falta ese contrapunto dramático entre el vacío de la tumba y los testigos del acontecimiento, aunque también es cierto que los evangelistas solo citan el sepulcro vacío y a las posteriores apariciones ${ }^{52}$.

Otras muchas contradicciones se observan en los diferentes flashbacks, pues cuando Jesús predica a las masas las exhorta a amar a los enemigos, pero más adelante se contradice cuando Gestas se mofa de Él; en la misma línea del escarnio al que la soldadesca lo somete antes de la flagelación, la exposición al pueblo por parte de Pilato o las burlas de los soldados a los pies de la cruz. Y ya crucificados, en medio de una alta dosis de sadismo gratuito, un cuervo se posa en el travesaño de la cruz de Gestas y le arranca los ojos ante el regocijo de la cámara. La costumbre romana establecía que los crucificados permanecieran colgados en las cruces durante varios días, a expensas de los pájaros carrońeros ${ }^{53}$. De modo que este hecho es lo que Gibson quiso reproducir con su escabrosa escena.

Su película es, a todos los efectos, trentina -Mel Gibson se declara trentino-, de modo que su «obra» juega el mismo papel que tenían las procesiones públicas en el Seiscientos, pues durante su recorrido provocaban sentimientos de repulsa, haciendo que los fieles/espectadores insultaran o escupieran a los sayones al paso de la comitiva ${ }^{54}$. Solo se ha sustituido la calle por la sala cinematográfica, y es muy probable que estas escenas gratuitas las hubieran eliminado los inquisidores del Santo Oficio, basándose en que no se ceñían a los Evangelios canónicos ${ }^{55}$. Quizás por este motivo, como si contestase a lo que aquéllos hubieran preguntado en un hipotético juicio inquisitorial, al ser entrevistado Gibson, en su defensa argumentó que

la película no es un documental histórico ni pretende haber recopilado todos los hechos. No es solamente representativa ni solamente expresiva. Pienso en ella como

51 Alonso López, J. (2017), pp. 111-136.

52 Según Marcos (Mc 16, 1), María Magdalena, María la de Santiago y Salomé fueron quienes encontraron la tumba vacía; Mateo $(\mathrm{Mt} 28,1)$ sin embargo dice que solo fueron dos mujeres, María Magdalena y la otra María. Lucas $(\operatorname{Lc} 24,10)$ habla de tres, pero a una de ellas la llama Juana, y por último Juan (Jn 20, 1-2) solo cita a María Magdalena.

53 Porter, J.R., p. 207.

${ }^{54}$ Martín González, J.J. (1993): «Arte procesional del Barroco». Cuadernos de Arte Español. Madrid: Historia 16.

55 Calero Ruiz, C. (2005), pp. 101-106. 


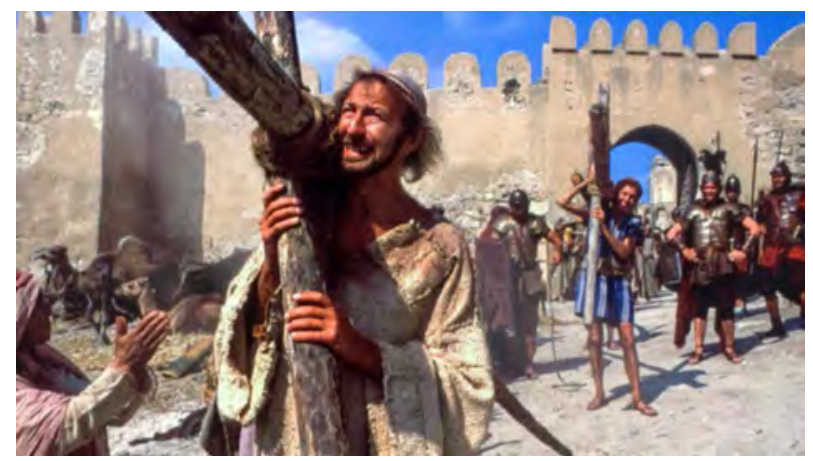

Foto 16. Graham Chapman en La vida de Brian (The Life of Brian, 1979).

contemplativa en el sentido en que uno está obligado a recordar (no olvidar) en una forma espiritual que no puede ser articulada, sino solo experimentada ${ }^{56}$.

Dos años después, y usando los mismos extras y las mismas localizaciones de Túnez y Marruecos de Zeffirelli, Terry Jones rodó La vida de Brian (The Life of Brian, 1979) [foto 16], protagonizada por el grupo inglés Monty Python, que cuenta la historia de un judío nacido el mismo día de Jesús, Brian Cohen (Graham Chapman), en el establo de al lado. Inspirada en la filosofía mesiánica, la trama se sitúa en la Palestina de la época de Cristo y en sus problemas políticos, donde el hijo bastardo de un soldado romano y una feminista judía es confundido con el Mesías. En ningún momento el grupo inglés pretendió recrear la vida de Jesús, pues según sus palabras ese tipo no es nada divertido, inventándose por tal motivo a Brian, un contemporáneo que sufre sus mismas situaciones,

un incompetente, un ser desdichado y gris, que por un azar se encuentra mitificado como un mesías redentor al que mucha gente sigue ciegamente sin cuestionar siquiera si es real la naturaleza que se le otorga. Ahí es donde la Monty Phyton como actores y guionistas meten el dedo en la llaga. ¿Detalles de mal gusto? Pues algunos. No siempre se acierta. Pero el tema central es incuestionable. ¿Para qué quereis un mesías? ¿Por qué no pensáis por vosotros mismos? ${ }^{357}$.

Su estreno generó una oleada de protestas entre los sectores ultraconservadores de todo el mundo, y se calificó a la película de blasfema al considerar que los cineastas se burlan del sufrimiento de Cristo, por lo que muchos países se nega-

56 Gil de Muro, E.T., p. 381.

57 SÁınz, L.: «Diario de cine. Antigüedad». Disponible en pdf en http://www.diariodecine.es/ssdvd234.html. Consultado el 22/5/2017. 
ron a exhibirla ${ }^{58}$. En Nueva York hubo manifestaciones de protesta, incluida una de rabinos, pero Terry Jones, su realizador, salió al paso de las críticas alegando que

no estaba atacando a Cristo. Es una película herética, pero no blasfema. Cogimos la historia y le pusimos tratamiento de comedia. Cristo era un buen hombre que decía cosas bellas. Lo malo es cómo se lo interpreta ${ }^{59}$.

Al margen de la polémica que suscitó, La vida de Brian ha pasado a la historia como una de las más disparatadas comedias del cine, y el máximo exponente del humor inglés. Existen, sin embargo, otras películas que han visto la pasión de Jesús con unos presupuestos radicalmente opuestos, confundiendo la forma con el fondo, el mensaje y el medio ${ }^{60}$. Es el caso del ya mentado El Evangelio según Mateo (Il Vangelo secondo Matteo, Pier Paolo Pasolini, 1964) ${ }^{61}$, donde en clave neorrealista se realiza un retrato de Jesús, presentándolo como un revolucionario que ha venido al mundo a confundir a las masas. Como hemos comentado antes, el personaje principal lo interpreta Enrique Irazoqui, que en principio denegó la invitación pero tras convencerlo el director, aceptó. Para ello debía olvidarse de los filmes anteriores, y pensar que los «malos» eran los carniceros de la policía de Franco, de modo que el actor interpretaba aquello furiosamente $e^{62}$. En este caso, igual que hizo Gibson, hay total connivencia con el espectador por la vía dramática. El rodaje se localizó, en ambos casos, en Matera, localidad de la región de Basilicata, en el sur de Italia, contratando no solo a actores poco conocidos, sino que los propios habitantes se transformaron en protagonistas para que la historia ganara en veracidad ${ }^{63}$. Los referentes plásticos, la música y numerosos detalles convirtieron a esta película en

un filme único, una propuesta que marca la buscada universalidad del proyecto y del sentimiento religioso que acaba expandiéndose a otras latitudes mostrando cómo la historia no tiene tiempo ni lugar, ya que pertenece a todos los pueblos ${ }^{64}$.

Sin embargo, no será hasta el siglo xxI, en el 2014, cuando el L'Osservatore Romano elogie la humanidad del realizador, pues en su opinión consiguió que tras-

58 En Italia se estrenó en 1991.

59 Gil de Muro, E.T., p. 380.

${ }^{60}$ Sola Antequera, D. (2008), p. 252.

${ }^{61}$ Cfr. Vaquero Argeles, M. (2006).

${ }^{62}$ Gil de Muro, E.T., p. 378. Este papel le supuso a Enrique Irazoqui la retirada en España de su pasaporte y la expulsión de la Universidad, por lo que se instaló en París, donde siguió estudiando: devolvia Cristo a las gentes sencillas a las que se les habia arrebatado.

${ }^{63}$ La Filmoteca vaticana ha digitalizado la película, y el papa Francisco la ha reconocido 50 años después de su estreno como «una representación que toca cuerdas sagradas y construye un sincero realismo».

${ }^{64}$ Sola Antequera, D. (2008), p. 255. 


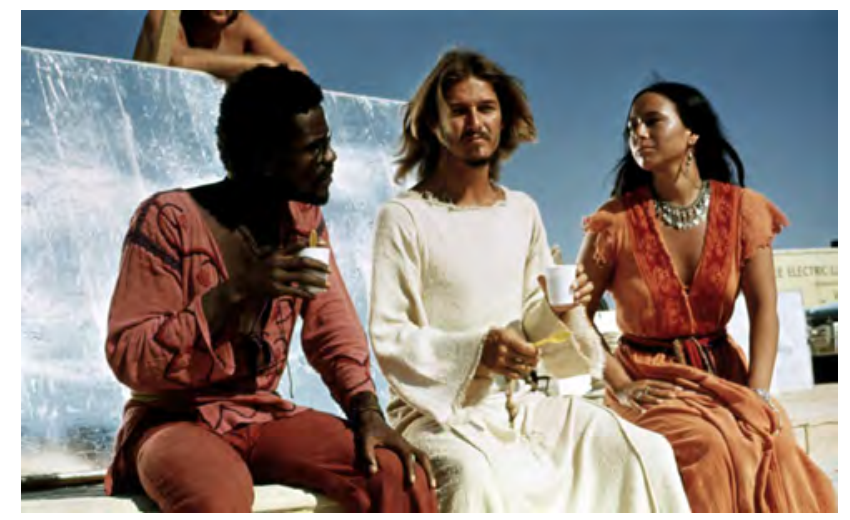

Foto 17. Carl Anderson (Judas), Ted Neely (Jesús) e Ivonne Ellimant (María Magdalena) en Jesucristo Superstar (Jesus Christ Superstar, Norman Jewison, 1973).

pasara la pantalla, dando un vigor nuevo al verbo cristiano. Es más, el Evangelio en este contexto aparece todavía más actual, concreto, revolucionario ${ }^{65}$.

En 1973 se estrenó otro hito, Jesucristo Superstar (Norman Jewison, 1973) [foto 17], adaptación de una ópera rock ${ }^{66}$, en la línea de los movimientos por los derechos humanos de los años setenta, que nos cuenta la vida de un Jesús más humano que divino. Se rodó en Israel, en los mismos escenarios por donde transcurrió la vida pública de Jesús y sus discípulos. La historia comienza con la llegada al lugar del rodaje de los actores y el atrezo, en un autobús escolar rotulado en árabe; son de diferente color y raza, y comienzan a montar los escenarios. La música de A Li Webber va generando el ambiente, ayudando a que cada actor se meta en la piel del personaje que le toca interpretar. La historia comienza con la entrada triunfal en una caótica y anacrónica Jerusalén, enclavada en medio de un desierto abrasador, habitada por hippies y una clase sacerdotal políticamente acomodada a los invasores romanos. Los personajes fundamentales de la historia están todos presentes: Jesús (Ted Neely) comparte protagonismo con el traidor Judas (Carl Anderson), María Magdalena (Yvonne Ellimant), enamorada de Jesús, Pilato (Berry Dennen) el cobarde, Caifás (Bob Bingham) el sacrílego y Herodes (Josh Mostel), que se mofa de sus milagros y le dice que le convierta el agua en vino o que camine sobre las aguas. Judas es quien va contando la historia y Jesús, conforme el filme avanza, se va enterando del destino que le espera.

${ }^{65}$ Fuentes, A.: «El Vaticano bendice, 50 años después, "El Evangelio según san Mateo" de Pasolini». L'Osservatore Romano, 29/7/2014.

${ }^{66}$ Basada en el musical del mismo nombre de Andrew Lloyd Webber y Tim Rice. 
En los años 80 La última tentación de Cristo (The Last Temptation of Christ, Martín Scorsese, 1988) ${ }^{67}$ inicia un cambio en este tipo de películas. Nos presenta a un Jesús (Willen Dafoe) tentado por el demonio y la carne, que se gana la vida como carpintero, construyendo cruces. Pero la historia da un giro inesperado cuando durante su crucifixión, un supuesto ángel le quita los clavos y lo libra del madero y del martirio, mostrándole la vida que como humano podría vivir casado, primero con María Magdalena, y luego con María de Betania, la hermana de Lázaro. Llegados a este punto la obra plantea esta pregunta: ¿qué hubiera pasado si Jesús no muere en la cruz sino que, desoyendo la llamada del Padre, se casa y tiene hijos? Estas imágenes, aparentemente reales, son solo una serie de secuencias con las que el ángel-demonio lo tienta mientras agoniza en la cruz. Un Jesús de carne y hueso que, tras ayunar en el desierto y rechazar las tentaciones de Satanás, comienza su vida pública predicando a los que esperaban su venida. El supuesto ser angélico le anuncia, además, que no es el Mesías y lo ayuda a bajar de la cruz. Mientras esto ocurre, los presentes al acto no advierten nada y continúan con su duelo particular como si nada pasara. Le enseña cómo se casa primero con María Magdalena, y en segundas nupcias con María de Betania, tiene hijos y un día se encuentra con Pablo, que predica sobre el sacrificio del Mesías en la cruz y su resurrección. Se le acerca y le dice que el hombre de quien habla es él, pero que vive como un hombre. Pablo le contesta que por su egoísmo los hombres son infelices y sufren porque su única esperanza es Jesús resucitado. Pasado el tiempo, cuando Jesús yace en su lecho de muerte, recibe la visita de algunos de los apóstoles, recriminándole Judas que no haya consumado su sacrificio, advirtiéndole que el ángel es Satanás, que lo está tentando y si muere lo hará como hombre pero nunca como Redentor, por lo que no habrá salvación para la humanidad. Percatándose de su egoísmo, pide perdón al Padre y solicita ser crucificado, siendo consciente en ese instante que nada de lo que había «experimentado» era real, solo eran alucinaciones, pues nunca fue desclavado vivo de la cruz, de la que siempre había estado colgado.

Este filme es de los pocos que se acercan a la realidad histórica respecto a cómo tuvo que haber sido la coronación de espinas, la subida al calvario y la crucifixión. La corona en realidad no es como nos la han presentado las artes plásticas y el cine, sino que en realidad es una especie de casquete, el pileus [foto 18]. El pileus se hacía con ramas espinosas y cubría toda la cabeza, desde la frente y la sien hasta la nuca; las espinas eran largas, duras y agudas, y atravesaban el cuero cabelludo hasta llegar al cráneo.

Tampoco la subida al calvario es como nos la han pintado o esculpido los artistas, pues el reo solo cargaba sobre sus hombros con el patibulum que se usaba como travesańo de la cruz, el stipe estaba clavado en el lugar de las ejecuciones [foto 19]. El reo muchas veces era atado con cuerdas al patibulum, aunque el uso de clavos está documentado por varias fuentes, entre ellas Flavio Josefo. También el Evangelio de San Juan señala el uso de clavos.

${ }^{67}$ Basada en la novela homónima de Nikos Kazantzakis. 

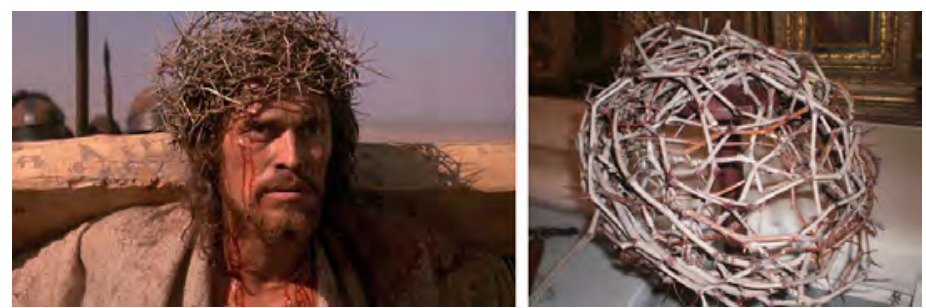

Foto 18. Willen Dafoe (Jesús) en La última tentación de Cristo (The Last Temptation of Christ, Martín Scorsese, 1988) y detalle de un pileus.
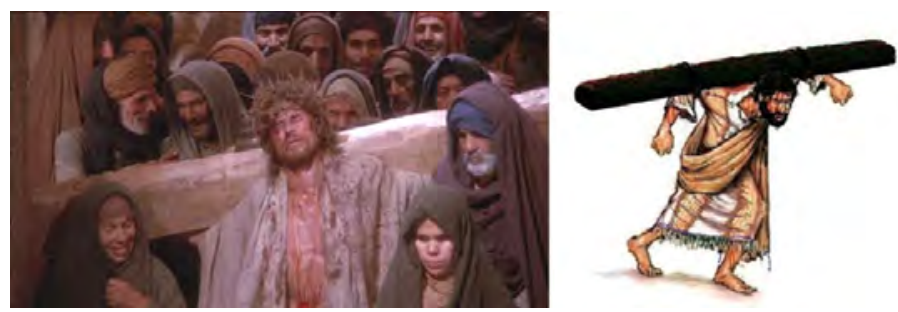

Foto 19. La última tentación de Cristo (The Last Temptation of Christ, Martín Scorsese, 1988).
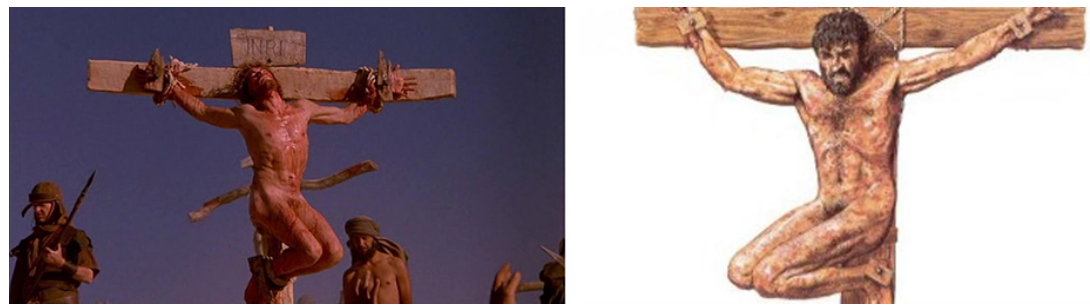

Foto 20. La última tentación de Cristo (The Last Temptation of Christ, Martín Scorsese, 1988).

La víctima era desnudada antes de ser clavada en la cruz, por lo que se consideraba una de las formas más vergonzosas y humillantes de morir. El mentado historiador judío Flavio Josefo nos ha dejado interesantes testimonios de esta clase de suplicio [foto 20]. La crucifixión se reservaba para los condenados por delitos políticos, pero no para crímenes más comunes, y supuestamente Jesús se había rebelado contra el orden establecido por Roma, de modo que debía morir en la cruz. En 1968, en el transcurso de las excavaciones que se efectuaban en Givat ha-Mitvar, al norte de Jerusalén, cerca de la Puerta de Damasco, se descubrieron varias tumbas del siglo I que contenían los restos de treinta y cinco cadáveres. El examen forense 


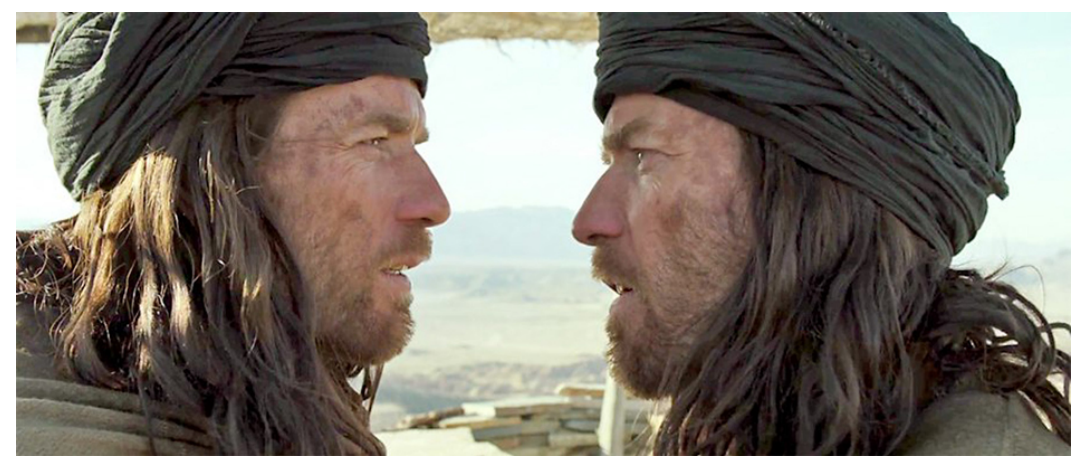

Foto 21. Ewan McGregor, Últimos dias en el desierto (Last Days in the Desert, 2015).

dictaminó que algunos habían sufrido atrozmente, y uno de ellos había sido crucificado: Yehohanán (su nombre estaba escrito en el osario), y sus talones habían sido atravesados por un clavo de unos dieciocho centímetros. El clavo primero atravesó una pieza de madera y luego los talones dispuestos en posición lateral. También observó que un clavo atravesó cada antebrazo, por debajo de la muñeca, entre el cúbito y el radio. De este modo, el cuerpo caería víctima de su propio peso, y el reo moriría asfixiado. Asimismo tenía fracturadas las rodillas y las tibias, para acelerar la muerte, lo que sabemos se le hizo a los dos ladrones que fueron crucificados junto a Jesús. Al Nazareno no se le partieron las piernas porque ya había fallecido ${ }^{68}$. En el siglo XXI el tema sigue interesando pero dándole un giro diferente, es así como Rodrigo García nos presenta en su Últimos días en el desierto (Last Days in the Desert, 2015) a un Jesús humano tentado por el diablo en medio de un árido paisaje, ante fatigas y alucinaciones producidas por el calor. En la película intervienen muy pocos personajes, además de Jesús y el diablo, ambos interpretados por Ewan McGregor [foto 21]; aparecen solo tres personas más, una familia anónima compuesta por un padre, una madre enferma y su hijo, con sus propios conflictos internos. El hijo lucha con el padre porque desea escapar de su destino -vivir en el desierto-y marchar a la ciudad, mientras que la madre está enferma, y el padre -un cantero- intenta construir una casa donde vivir en medio de la nada.

En 2016 se estrenó El Apóstol Pedro: Redención (The Apostle Peter: Redemtion, Leif Bristow), donde el protagonista es Pedro (John Rhys-Davies), el apóstol que pasa su vida atormentado y arrepentido por haber negado a Jesús, y que ahora que se enfrenta a la muerte, intenta reparar sus fracasos. El mismo año llega a las salas de cine Resucitado (Risen, Kevin Reynolds, 2016) [foto 22], también conocida como Resurrección, Resucitado o La Resurrección de Cristo, título que se le dio en His-

68 Alonso López, J. (2004), pp. 189-190. 


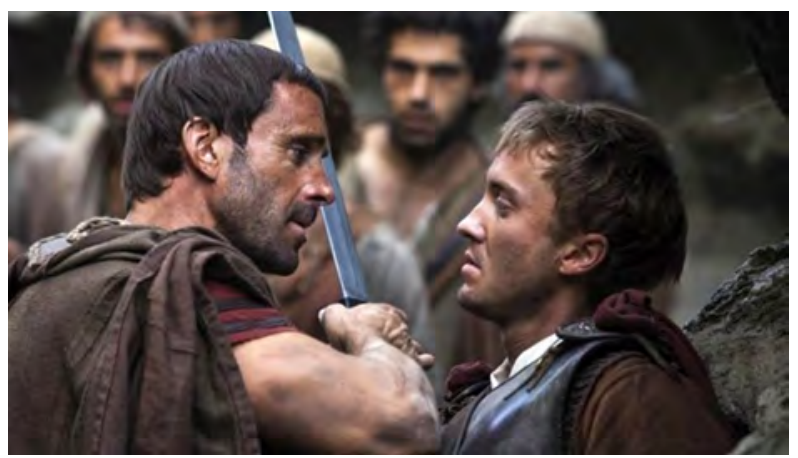

Foto 22. Joseph Fiennes (Clavius Valerirus) en Resucitado (Risen, Kevin Reynolds, 2016).

panoamérica $^{69}$. El protagonista es Clavius Valerirus (Joseph Fiennes), un tribuno romano a quien Poncio Pilato (Peter Firth) le encarga la misión de ejecutar la pena capitata (cucifixión) de tres rebeldes, uno de ellos de nombre Yeshua ben Josef; debe además encargarse de velar por su sepultura y vigilar la tumba. Tras enterarse de que los soldados a su mando habían desaparecido y que la tumba estaba vacía, Pilato le encarga investigar los rumores sobre la «supuesta» desaparición del cadáver del Nazareno (Cliff Curtis). A lo largo de la misión las dudas terminan haciendo mella en él, tras entrevistar a diferentes personajes que tuvieron relación directa con Jesús, algunos apóstoles y discípulos que le cuentan los extraños fenómenos atmosféricos y geológicos que se sucedieron tras la exhalación de su último suspiro en la cruz. Un día, sorprende en una habitación a los apóstoles, a los que Yeshua les está mostrando sus heridas. Impresionado decide seguirlos para averiguar la verdad sobre el personaje $\mathrm{e}^{70}$.

Una de las últimas películas tiene como protagonista a María Magdalena (Mary Magdalene, Garth Davis, 2018) [foto 23], papel interpretado por Rooney Mara, quien en el año 33 d.C., cuando Judea estaba controlada por Roma, y desafiando a su familia, comienza a seguir a Jesús (Joaquín Phoenix), convirtiéndose en una discípula más, lo que le traerá conflictos con algunos de los apóstoles, incluido Pedro (Chiwetel Ejiofor), que no ven correcto que Jesús haya escogido a una mujer para guiarlos. En esta ocasión se le ha dado un enfoque diferente a esta mujer calificada como una prostituta redimida por Jesús, para convertirla en una adelantada de su época, con un protagonismo mayor del que siempre se ha creído que tuvo. De hecho fue a ella a quien primero se le apareció Jesús tras la resurrección, encargándole la misión de comunicarlo a los discípulos.

${ }^{69}$ La película está protagonizada por Joseph Fiennes, Tom Felton, Peter Firth y Cliff Curtis y se estrenó en España el 23 de marzo de 2016.

${ }^{70}$ Se supone que la trama de la película se basa en la novela de Stephen Dandoi Collins (2008) El informe de Judea. 


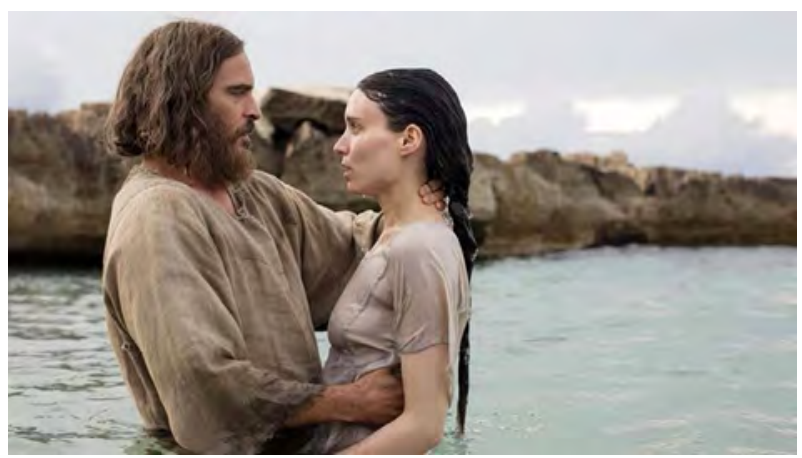

Foto 23. Rooney Mara (María Magdalena) y Joaquin Phoenix (Jesús) en Mary Magdalene (Garth Davis, 2018).

El Evangelio de Juan (Jn 16, 7-13) nos dice cómo Jesús ascendió a los cielos en presencia de María Magdalena en el jardín del sepulcro. Y después de la resurrección, le prohíbe que lo toque pues todavia no he subido al Padre, pidiéndole que busque a los discípulos y les transmita este mensaje: Voy a subir a mi Padre y a vuestro Padre; a mi Dios, y a vuestro Dios (Jn 20, 17), y ese mismo día, por la tarde, en presencia de los apóstoles, reciben al Espíritu Santo (Jn 20, 22).

Es probable que los guionistas hayan acudido al propio Evangelio apócrifo de María Magdalena, evitando presentarla como una cortesana arrepentida, tal y como se ha hecho siempre, especialmente a partir del papa Gregorio Magno en el año 591. Pues en la película se la presenta como una mujer sensible e inteligente, convertida en Mulieres Dignitatem, como la definió el papa Juan Pablo II: la apóstola de los apóstoles, corroborado posteriormente por el actual papa Francisco, instituyendo su fiesta en el calendario romano, como al resto de los apóstoles, el día 22 de julio.

La historia la llevará a Jerusalén, para unir su destino al de Jesús, vaticinado por María cuando le pregunta: Amas a mi hijo, ¿verdad? Pues entonces debes prepararte, como yo, para perderlo. Se da una visión más humana y cercana de esta mujer, que hará que otras mujeres, siguiendo su ejemplo, sigan al Rabino. Incluso sean bautizadas por ella, pues dado que la tradición no permitía que se bautizaran juntos hombres y mujeres, Jesús le dice que bautice en su nombre y sus manos serán las de ella. Centrada sobre todo en la vida pública de Jesús, toca poco las escenas pasionistas, pues la protagonista es Magdalena, convertida en su confidente, permitiéndole conocerlo mucho mejor que al resto de los apóstoles. 